\title{
The Future of the OSCE: Government Views
}

Frank Evers and Argyro Kartsonaki, editors"

\section{Abstract}

This special issue of OSCE Insights sheds light on what the governments of OSCE participating States expect from the OSCE. The contributions examine the planning and intentions of eight states as of 2021: France, Kazakhstan, North Macedonia, Poland, Russia, Sweden, Turkey, and the United States. The authors also elaborate on perceived limitations of the OSCE and suggest ways forward. This special issue contributes to the discussion on how to make the OSCE more relevant for the foreign policies of its participating States and more effective in fulfilling its purpose, ahead of its $50^{\text {th }}$ anniversary in 2025 .

Keywords

OSCE, conflict management, foreign policy, international organizations, multilateralism, human rights

To cite this publication: Frank Evers and Argyro Kartsonaki (eds.), The Future of the OSCE: Government Views, OSCE Insights 5/2021, Special Issue (Baden-Baden: Nomos, 2022), https://d oi.org/10.5771/9783748911456-05

* Frank Evers

Institute for Peace Research and Security Policy at the University of Hamburg evers@ifsh.de

Argyro Kartsonaki

Institute for Peace Research and Security Policy at the University of Hamburg kartsonaki@ifsh.de 


\section{Introduction}

\section{Frank Evers and Argyro Kartsonaki}

Despite the deteriorating security situation in the OSCE area, governments are not making full use of the OSCE. Why is this so? This special issue of OSCE Insights sheds light on what the governments of selected participating States expect from the OSCE ahead of its $50^{\text {th }}$ anniversary in 2025. It seeks to determine whether there are governments that intend to use the Organization more effectively than they have in the past and how it could become more relevant for them. The contributions to this issue examine the views of the governments of eight OSCE participating States. Some the United States and Russia - are global powers; others - France, Turkey, and Kazakhstan - are regionally significant. Four are past, current or future Chairs of the Organization: Kazakhstan (2010), Sweden (2021), Poland (2022), and North Macedonia (2023).

The authors were invited to present the governments' perceptions of the OSCE's significance for their foreign and security policy planning, also in comparison with other international organizations. Each case study describes the respective government's expectations of and intended engagement with the OSCE and shows where it identifies limitations. To some extent, the papers also present the views of academia and civil society, at the same time demonstrating that the OSCE is not widely discussed beyond government circles. Finally, they provide outlooks or recommendations regarding the future engagement of the respective state with the OSCE.

Several of the authors have worked with their respective governments for many years. This means that they have inside knowledge, but also that some of them tend not to be particularly government-critical. As a result, some papers are dominated by their governments' points of view on certain issues. Certain topics are less prominent than might be expected. In that sense, some of the contributions speak through that which they omit.

Regarding data collection, the authors mainly relied on interviews with government and OSCE officials, public government statements, and non-published material pertaining to ongoing policy planning.

\section{What the case studies show}

Presenting the United States' view, Daniel Hamilton explains that although the OSCE has received only sporadic presidential attention to date, the US Congress has consistently engaged with the Organization through the Helsinki Commission. The latter has been discussing OSCE matters in Washington, DC, since 1976, and its members regularly participate in the US's OSCE delegation in Vienna. The US has also remained steadily committed to OSCE activities on the ground. Hamilton argues 
that for the US, the OSCE is an instrument for advancing the country's interests, especially in the fields of managing conflicts and protecting human rights. He predicts that the Biden administration will be more engaged in the OSCE than previous administrations. The US is committed to all three OSCE dimensions, whereby conventional arms control, conflict prevention and resolution, supporting human rights and fundamental freedoms, and addressing terrorism and human trafficking occupy a prominent position. With respect to US-Russia disputes over politico-military security, unresolved conflicts, and human rights, Hamilton suggests that the "US-Russia strategic stability talks now underway could be complemented by similar discussions among OSCE participating States.”

Andrei Zagorski presents Russia's criticism and expectations of the OSCE. Russia regards the OSCE as having been appropriated by the West to facilitate US, EU, and NATO interference into countries' domestic affairs, with the aim of imposing Western-type political regimes. Moscow is critical of activities in the human dimension of the OSCE, considering them to be both biased and obsolete. Russia has for many years been interested in turning the OSCE into a treaty-based organization and in resuming substantive negotiations within the OSCE to agree on a new common ground between Russia and the West. Regarding areas for cooperation, Russia prioritizes dealing with transnational threats such as terrorism and organized crime and risks of conflict stemming from information and communication technologies. The Russian gov- ernment also sees potential for cooperation in the second dimension, especially regarding the connectivity agenda.

Barbara Kunz explains France's contradictory attitude towards the OSCE. On the one hand, France is a committed participating State that actively contributes to the Organization's day-to-day operations and conflict resolution initiatives. Also, as the birthplace of the 1789 Declaration of the Rights of Man and of the Citizen, France feels a special responsibility to support human rights. France uses its participation in high-level OSCE conflict resolution efforts to reaffirm its selfperception as a global power, for example as a member of the Normandy format on Ukraine or as Co-Chair of the Minsk Group on Nagorno-Karabakh. However, the OSCE matters little in France's pursuit of its foreign policy objectives. Paris seems to believe that multilateral organizations such as the OSCE are incapable of delivering quick results. Furthermore, "the OSCE does not cover the geographic area that most interests France." France rather pursues its objectives either bilaterally or through other multilateral platforms, and its engagement with the OSCE remains limited. Therefore, France is not prepared to take a leading role in the Organization or to take any initiatives to make it more effective.

As is the case for most of the states discussed in this special issue, the most important OSCE dimension for Turkey is the politico-military one. Giray Sadik explains that Turkey's primary interest in the OSCE is for it to become more effective in stabilizing crises in the country's immediate neighbourhood, although he 
does not address Turkey's military posturing there. He states that the OSCE should better exploit its conflict management tools to facilitate the resolution of protracted conflicts. Other priorities for Turkey are the fight against terrorism and transnational organized crime, especially human trafficking, and efforts against xenophobia and Islamophobia, mainly regarding the Turkish diaspora in Europe. The lack of progress on the latter issue is the main object of Turkey's criticism of the OSCE. The author, while not discussing domestic issues, points to the need to strengthen ODIHR, especially as concerns the reporting of hate crime and the integration of migrants.

The OSCE has a prominent place in Kazakhstan's political rhetoric; nonetheless, this discourse has not been accompanied by systematic action. Rustam Burnashev and Irina Chernykh show that Kazakhstan's engagement with the OSCE is ad hoc and primarily reactive. Kazakhstan uses the OSCE as a platform to hone its international image and demonstrate its institutional capacities, as shown during its 2010 OSCE Chairpersonship. Despite its declaratory recognition of the OSCE's importance, the government regards its principles and norms as externally imposed on Kazakhstan. It sees the OSCE as only one among several European and Eurasian organizations. Moreover, it believes that OSCE officials and experts working in the country lack sufficient understanding of local needs, compromising their ability to design appropriate activities on the ground. While Kazakhstan's expectations pertain primarily to the OSCE's first dimension, the government also views the second dimension as a vehicle for building confidence and reducing tensions in the region. Kazakhstan seeks to raise its profile in this area by, inter alia, using the occasion of disputes over the OSCE Programme Office in Nur-Sultan to campaign for an OSCE thematic regional connectivity hub in the country.

Lars-Erik Lundin presents Sweden's concerns and actions as 2021 Chair of the OSCE. The Swedish Chairpersonship is focused on three priorities: safeguarding the European security order; protecting comprehensive security; and promoting conflict resolution through small steps. One of its main aims is to "go back to basics", meaning, first, to secure a functioning OSCE and, second, to re-establish compliance with OSCE principles. Sweden emphasizes the issue of human rights, regarding it as a cross-dimensional topic that has a direct impact on the other two OSCE dimensions. Sweden is particularly concerned about the escalation of crises in its eastern neighbourhood and military threats to Sweden and Northern Europe. With that in mind, Sweden seeks to pursue its security interests through NATO cooperation, EU membership, solidarity with Nordic states, and special relations with the United States. Against this background, Lundin explains that Sweden sees the OSCE as a means to complement its military defence through confidence building.

According to Łukasz Kulesa, Poland, the OSCE Chair for 2022, also feels increasingly threatened by the developments beyond its eastern borders. While it considers the OSCE a valuable part 
of the European security order, it prioritizes cooperation and engagement with other international organizations and political groupings, notably NATO and the EU. The Polish government considers the latter more effective in securing Polish foreign and security policy interests, especially when it comes to crises in Central and Eastern Europe. Kulesa claims that the main value of the OSCE for Poland is that it provides a forum for dialogue "when other channels of communication remain closed or severely constrained". Thus, the OSCE might not be able to resolve ongoing conflicts, but it can provide an inclusive framework to facilitate the solutions to be achieved elsewhere. Therefore, Poland aims to remain active within the OSCE as part of its strategy of engaging in multilateralism to promote stability in Europe, which was also one of its main incentives for applying for the 2022 OSCE Chairpersonship.

In her contribution on North Macedonia, which will chair the OSCE in 2023, Ana Krstinovska shows that the OSCE's importance for the country has diminished in recent years in comparison to other organizations. The OSCE's support for the process of democratic reform underway in the country is perceived as being beneficial to North Macedonia internally and with respect to its international integration. By contrast, the government prefers to pursue its hard security interests not through the OSCE but rather through NATO. North Macedonia's engagement with the OSCE is pragmatic rather than strategic. It sees the OSCE as an organization that supports the country in achieving its strategic goals of joining the EU and meeting the Sustainable Development Goals. At the same time, it sees the assumption of the 2023 Chairpersonship as a great opportunity to demonstrate its progress in building democratic institutions and to boost its international image.

\section{Conclusion}

None of the eight states discussed in this special issue is presented as showing an extraordinary interest in increasing its engagement with the OSCE. Most governments do not see the OSCE as a major security player and prefer to pursue their foreign policy objectives through other platforms. This in itself is not surprising. The OSCE's role has diminished in comparison with other international organizations, and governments have been questioning its value in different contexts and situations for many years.

At the same time, each of the authors notes an interest in keeping the OSCE functioning. This is a thread that runs throughout the contributions, especially those pertaining to Chairpersonship states. In one way or another, they all acknowledge that the OSCE offers an inclusive space for dialogue, where security concerns can be put on the table without delay or preparatory negotiations. Thus, the OSCE is seen as an important element of multilateral security-building. Some papers, particularly those on countries in Russia's vicinity, also mention that the OSCE is seen as a platform for complementing deterrence with cooperative security in the face of a growing per- 
ception of threat to their national security. Furthermore, many states seek more intensive OSCE engagement in conflict management. The view that the OSCE should take a more results-oriented approach to the resolution of protracted conflicts is prominent in most of the contributions, without these conflicts and other disputed issues necessarily being seen solely in the light of Western-Russian relations. Moreover, governments have different views on how and whether to use the OSCE to protect human rights. Some states would lead the way towards this goal, while others see it as imposing foreign values and interfering in internal affairs. This is not new. At the same time, we read between the lines that some governments are using the need to address human dimension concerns as a pretext to advance other domestic and foreign policy objectives.

Looking beyond the contributions of this special issue, it will be necessary to examine more closely whether and why different governments want to keep the OSCE alive. We would like to draw attention to the fact that, despite the secondary importance the governments presented here tend to attribute to the OSCE, there have been renewed deliberations among some delegations in Vienna on the role the Organization should play in ensuring Europe's common security. In their view, multilateral dialogue must once again be made a defining element of European security relations, and this has to be brought to the attention of decision-makers in their capitals. Along these lines, we support the idea of bringing interested governments together in an in- formal Group of Friends of the OSCE to discuss an agenda for pragmatic cooperation on the way to the OSCE's $50^{\text {th }}$ anniversary in 2025 . 


\title{
The United States and the OSCE
}

\author{
Daniel S. Hamilton"
}

\section{Abstract}

The United States' approach to the OSCE has been distinguished by sporadic presidential attention, persistent on-the-ground mid-level diplomacy, and unique engagement by the US Congress through the Helsinki Commission. The Biden administration is showing signs of injecting new energy into US-OSCE relations, including for addressing unconventional security threats such as corrosive cyber operations and the COVID-19 pandemic. For the US, the OSCE is not an end in itself; it is a means by which its policy interests may be advanced, particularly via the principles that were enshrined in the 1975 Helsinki Final Act and the 1990 Charter of Paris.

\section{Scattered presidential attention}

Bill Clinton was the US President most actively engaged with the OSCE, as measured by his attendance at both the 1994 Budapest Summit, in which the CSCE formally became the OSCE, and the 1999 Istanbul Summit. At a time when the Soviet empire had collapsed and the Soviet Union, Yugoslavia, and Czechoslovakia dissolved into twenty new countries, many with unresolved and often conflicting historical resentments and territorial and ethnic disputes, President Clinton and his administration were concerned that the greatest threats to security in Europe were as likely to come from

* Daniel S. Hamilton

Woodrow Wilson International Center for Scholars

dan.hamilton@wilsoncenter.org conflicts within states as between them. The Clinton administration believed the OSCE would be able to make a unique contribution in this situation, as it was grounded in the principle that the root of human insecurity is the denial of human rights. ${ }^{1}$

The Clinton administration sought to construct a post-Cold War European security architecture in which the OSCE could become the institution of choice when it came to conflict resolution, the expansion and protection of democracy and democratic institutions, the defence of human rights, fundamental freedoms, and the rule of law, and identifying and addressing economic issues that could lead to conflict and threats to security across the Eurasian-Euro-Atlantic space. By the end of Clinton's time in office in 2000, William Hill could write that "the OSCE truly flowered [...] perhaps reaching the zenith of its activity and influ- 
ence," ${ }^{2}$ with twenty missions and about 3,000 personnel in the field, breaking new ground with a broad and flexible array of tools for conflict prevention, crisis management, and post-conflict rehabilitation.

Since that period of "architectural construction", the OSCE has received far less US presidential attention and direction. "Benign neglect" is the term P. Terrence Hopmann has used to characterize highlevel US attitudes towards the OSCE between 2001 and 2014. ${ }^{3}$ George W. Bush focused largely on his counterterror campaign in the wake of the attacks of September 11, 2001, on the war in Iraq, and on NATO's "big bang" expansion. The OSCE hardly played a role in his calculations. Barack Obama also paid little attention to the OSCE during his first term in office, preferring to leave what seemed to be a relatively stable continent to European allies and to downplay USRussian ties. Only with Russia's illegal annexation of the Ukrainian peninsula of Crimea and its armed intervention in eastern Ukraine did high-level US attention focus again on the OSCE, both as a platform through which Russia's violation of basic OSCE norms and principles could be challenged and as a mechanism by which Russian activities could be monitored and contained.

The nadir of presidential attention to the OSCE came during Donald Trump's four-year term in office. Trump disregarded the Organization and openly disputed basic principles enshrined in the Charter of Paris. He questioned the importance of human rights as a guiding principle of US foreign policy and was openly disdainful of priorities important to the OSCE, whether anti-corruption efforts, the protection of minority rights, or military confidence-building measures. During Trump's term in office, the United States withdrew from the 1992 Open Skies Treaty, which was designed to enhance mutual understanding, build confidence, and promote the openness and transparency of military forces and activities.

\section{Principled diplomatic engagement}

Despite the scattered presidential attention paid to the OSCE, US diplomats have engaged with persistence and determination to advance the country's positions on OSCE-relevant issues. They highlight the OSCE's value as the only pan-European security organization that spans the Euro-Atlantic region and includes the United States, Canada, Russia, and all European and Central Asian states, plus Mongolia, as members. US diplomats consistently underscore the OSCE's contributions to Europe's military security through its extensive regime of confidence-building and transparency measures, verification procedures, and early warning mechanisms, which have helped to reduce levels of arms and tensions across much of the continent.

US diplomats promote the implementation of OSCE commitments across the board, in the politico-military, economic, environmental, and human dimensions. This includes: enhancing political and military security across the OSCE region; implementing and verifying compliance 
with arms control agreements; strengthening the OSCE's conflict prevention and resolution capabilities; supporting democracy, the rule of law, and respect for human rights and fundamental freedoms; combating such security threats as terrorism, intolerance, mis- and disinformation, and human trafficking; and directing greater attention and resources to Central Asia. US officials have pushed for the OSCE to become more operational in these areas. They have lent particular support to OSCE field missions, as well as the OSCE institutions. Biden administration officials have underscored that such support will continue.

\section{The Helsinki Commission}

The story of US engagement with the OSCE would not be complete without reference to the prominent role played by the US Congress. Just one year after the Helsinki Final Act was signed in 1975, the Congress created the Commission on Security and Cooperation in Europe, better known as the Helsinki Commission, to monitor and encourage all elements of the Helsinki Final Act. The Commission is bipartisan and consists of members of both the US Senate and the House of Representatives, who are selected by the President of the Senate and the Speaker of the House, respectively. Three additional Commissioners are appointed by the President of the United States from the Departments of State, Defense, and Commerce. Executive branch participation has been uneven, however; the Commission is clearly driven by the Congress.
Members of Congress have consistently held leadership positions in the OSCE Parliamentary Assembly since its inception. With 17 of 323 seats, the United States has the largest representation in the Assembly. The Helsinki Commission has its own representative posted outside the United States, at the US Mission to the OSCE, reflecting unique cooperation between the executive and legislative branches of government.

Although the Commission's attention extends to all areas of the OSCE's work, its legislative mandate includes a specific focus on human rights. Helsinki Commission members and staff participate in US delegations to OSCE meetings and in certain OSCE bodies. The Commission convenes public hearings and briefings with expert witnesses on OSCE-related issues and publishes public reports concerning the implementation of OSCE commitments in participating States. It organizes official delegations to participating States and OSCE meetings to address and assess developments concerning democratic, economic, security, and human rights first-hand. It regularly draws attention to human rights and security challenges in participating States, including racism, anti-Semitism, and intolerance; corruption; human trafficking; upholding the right of peaceful assembly and association; and protecting vulnerable communities, including migrants, from discrimination and violence.

The Commission has been particularly blunt in condemning Russia, Belarus, Turkey, and a number of Central Asian states, not only for stifling dissent in their own countries, but also for seeking to 
undermine the OSCE's work defending fundamental freedoms and to curtail civil society's participation in OSCE activities. The Commission played a central role in drafting the 2012 Magnitsky Act to impose sanctions on Russian officials responsible for the death of Russian lawyer Sergei Magnitsky in a Moscow prison in 2009 , as well as for other human rights abuses and corruption. The Chair of the Helsinki Commission, US Senator Ben Cardin, was integrally involved in the passage of the Magnitsky Act, as well as the 2016 Global Magnitsky Human Rights Accountability Act, which has been utilized by US presidents of both parties to sanction corrupt actors around the world and has inspired similar legislation in Canada, the UK, and the EU.

In 2021, the US Helsinki Commission has focused on the United States' interest in taking an active role in preventing mass killings, war crimes, crimes against humanity, and genocide. It has reviewed warning signs that indicate risks for atrocities and discussed the challenges of building and sustaining alliances among states in support of atrocities prevention. It has highlighted threats to US and global supply chains created by authoritarian regimes and has recommended that the OSCE Parliamentary Assembly endorse a Secure Supply Chains Initiative as a precursor to steps that governments of OSCE participating States might take on the issue. ${ }^{4}$

The Commission has also been contrite when it comes to assessing US adherence to its OSCE commitments, hosting, for instance, a series of self-critical hearings in 2020 looking at "human rights at home". In particular, the hearings considered how the US can make its commitment to racial justice visible through the protection of civil rights to free assembly and the protection of journalists. They considered the role of public monuments and memorials, particularly those stemming from the Civil War or celebrating figures associated with racial repression and slavery, and ways to move towards restorative justice.

\section{The Biden administration and the OSCE}

President Biden's nomination of his close advisor Michael Carpenter as Ambassador to the OSCE is an early sign that the Biden administration will take an energetic and productive approach to the OSCE. Only weeks after the administration took office, officials used the opportunity of the US Chairpersonship of the OSCE's Forum for Security Cooperation (FSC) to push for rebuilding military transparency and confidence through an updated Vienna Document, which has not been revised since 2011. Issues under consideration include giving lower thresholds for notification and international observation of military exercises, raising quotas for such inspections, reviewing categories for information exchange, and revising the definition of "unusual military activities". Expanded discussions, including among militaries, could address the potentially destabilizing security effects of new technologies. ${ }^{5}$ US officials have also pushed the OSCE to address protracted conflicts and to consider more specific outcomes regard- 
ing economic and environmental issues. They have also advocated for the implementation of UNSC Resolution 1325 on Women, Peace and Security in the FSC's work and for the OSCE to hold a Human Dimension Implementation Meeting in 2021.

These signs of new energy have been paired with condemnation of Russia's actions in Ukraine and elsewhere as the primary cause of the broad deterioration of the European security environment. The Biden administration will continue to challenge Russia on its failure to uphold its OSCE commitments and its brazen violation of them with its armed interventions in Georgia in 2008 and in Ukraine in 2014. US officials continue to call on Russia to implement its Minsk commitments regarding Ukraine and have reiterated that the United States "will never recognize Russia's purported annexation of Crimea". ${ }^{6}$ The Biden administration supports the continued extension of the OSCE Border Observation Mission at two Russian checkpoints on the Ukrainian border. US officials regularly highlight that the Special Monitoring Mission (SMM) to Ukraine has a mandate to work throughout Ukraine, including in Crimea, and continue to call on Ukraine, Russia, and the forces Russia arms, trains, leads, and fights alongside to ensure that the SMM has unfettered movement throughout the entire territory of Ukraine and to guarantee the safety and security of SMM monitors. They continue to point out that Moscow's forces are also deployed in Moldova and Georgia without host nation consent and that Russia's use of disinformation and other hybrid methods is an omnipresent challenge to all OSCE countries. They have also highlighted the continued violation of human rights and fundamental freedoms in Russia under Putin's government, including through recent efforts to clamp down on freedom of expression and freedom of the press by significantly expanding the scope of the so-called "foreign agent" rules, rendering individual journalists vulnerable to designation and increasing government censorship tools.

The Biden administration has not limited its critique to Russia. It has spoken out about how OSCE commitments have been broken and human rights brutally violated in Belarus. It has demanded that the Belarusian authorities release political prisoners, journalists, and all those unjustly detained and engage in meaningful dialogue with the Coordination Council and Belarusian civil society. The administration and Helsinki Commission members vocally condemned the forced landing of a commercial airplane by Belarus to arrest Belarusian activist and journalist Raman Pratasevich and civil society activist Sofia Sapega. While the situation in Belarus remains difficult, US officials see scope for greater OSCE involvement, including through the Secretary General's good offices. US officials have also called out some governments that are using COVID-19 as a cover for cracking down on civil society and independent media, further restricting public access to information and undermining the rule of law. Together with the Helsinki Commission, they have shone a light on the targeting of racial, ethnic, and religious 
minorities, as well as other vulnerable populations such as LGBTI individuals.

Another issue on which the Biden administration has signalled interest is a more engaged role in the NagornoKarabakh conflict. Even during his election campaign, Biden drew attention to the OSCE's potential monitoring role in the conflict. Secretary of State Antony Blinken has since committed to re-engaging with the OSCE Minsk Group. Administration officials continue to urge both Armenia and Azerbaijan to return as soon as possible to substantive negotiations under the auspices of the OSCE Minsk Group Co-Chairs (France, Russia, and the US) to achieve a long-term political settlement based on the principles of the Helsinki Final Act.

Furthermore, the administration has already shown signs that it intends to raise the profile of the OSCE's second dimension on economic and environmental issues and to address ways to anticipate, prevent, and if necessary confront future public health emergencies and pandemics. Officials believe that the OSCE could be an important vehicle through which to address climate change issues in Central Asia and the South Caucasus. It has supported the prioritization of climate change issues by the 2021 OSCE Chair, Sweden.

Finally, echoing the OSCE's determination that corruption is a threat to security, economic development, and respect for human rights, President Biden has designated the fight against corruption as a "core US national security interest". $\mathrm{He}$ has directed an inter-agency review within the US government to define an all-of-government security strategy to address corruption. The Helsinki Commission has welcomed this review and is likely to work closely with the Biden administration on its implementation.

\section{Looking ahead: Future scenarios}

Even though many participating States have fallen short of their OSCE commitments, US officials continue to underscore the value of the OSCE and that it is far better to work to improve it than to abandon it - all the more since the 1975 Helsinki principles and the 1990 Paris principles remain high-water marks in terms of commitments to a comprehensive approach, embracing the military, economic, environmental, and human dimensions of security.

There are several areas in which reinvigorated US engagement with the OSCE could pay dividends. ${ }^{7}$ Deconfliction arrangements devised for US and Russian forces in Syria could offer a model for similar arrangements under OSCE auspices related to air and sea disputes in and around the Black Sea. Bilateral US-Russia strategic stability talks underway in 2021 could be complemented by similar discussions among OSCE participating States. NATO's withdrawal from Afghanistan has awakened security concerns among Central Asian countries. The US will want to explore possibilities for expanded OSCE activities there, potentially including new field missions. There is also scope for the OSCE to facilitate some transborder initiatives in the South Caucasus, including the Ar- 
menia-Azerbaijan-Turkey corridor. And while Russia has taken on peacekeeping duties following armed conflict between Armenia and Azerbaijan in the autumn of 2020, over time Moscow may not want to bear those costs and burdens, potentially opening the way for a multinational, civilian, OSCE-led monitoring mission.

Societies across the OSCE space face unconventional security challenges that were not anticipated when participating States of uncommon cause gathered almost half a century ago to thrash out principles to guide their behaviour. ${ }^{8}$ Corrosive cyber operations, dis- and misinformation in social media, disruptions to supply chains, and the COVID-19 pandemic have each underscored that essential flows of people, goods, services, transportation, food, money, and ideas that power societies are increasingly susceptible to disruption. There is a growing need for the OSCE's participating States to define resilience principles that can guide behaviour when it comes to anticipating, preventing, and, if necessary, protecting against and bouncing forward from disruptions to critical societal functions. The OSCE remains a platform in which the unlike-minded can explore rules of the road in areas of security, such as resilience and connectivity, that remain relatively unexplored - if they choose to do so. If they do not, the United States and other participating States will define those principles elsewhere.

\section{Notes}

1 For a representative view: Remarks by US President Bill Clinton at the Opening of the OSCE Summit, Ciragan Palace, Istanbul, Turkey, 18 November 1999. See also Richard C. Holbrooke, "America, a European power", Foreign Affairs, March/April 1995, https://www.foreignaf fairs.com/articles/europe/1995-03-01/ame rica-european-power

William Hill, No Place for Russia: European Security Institutions Since 1989, New York: Columbia University Press, 2019, p. 153.

3 P. Terrence Hopmann, "Trump, Putin, and the OSCE”, in: IFSH (ed.), OSCE Yearbook 2018, Baden-Baden: Nomos, 2019, 39-52.

4 See "The ties that bind: A Helsinki Commission staff report on secure supply chains", US Helsinki Commission/Wilson Center, June 2021, https://www.wil soncenter.org/sites/default/files/media/up loads/documents/Ties_that_Bind.pdf

5 Almost all OSCE participating States support such an effort, yet Moscow remains opposed and Armenia and Azerbaijan are also blocking progress due to issues related to their bilateral disputes.

"Interpretative statement on the extension of the mandate of the OSCE Special Monitoring Mission to Ukraine, as prepared for delivery by Chargé d'Affaires Courtney Austrian to the Permanent Council, Vienna, March 31, 2021", U.S. Mission to the OSCE, 31 March 2021, https://osce.usmission.gov/interpretativ e-statement-on-the-extension-of-the-ma ndate-of-the-osce-special-monitoring-m ission-to-ukraine/; "Statement by President Biden on the anniversary of Russia's illegal invasion of Ukraine, the White House", 26 February 2021, https://www .whitehouse.gov/briefing-room/statemen ts-releases/2021/02/26/statement-by-presi dent-biden-on-the-anniversary-of-russias-i llegal-invasion-of-ukraine/ 
7 For US and European perspectives on a future agenda for the OSCE, see Daniel S. Hamilton et al., "Uncommon cause: The future of the OSCE - Report and recommendations, Global Europe Program Working Group on the Future of the OSCE”, Wilson Center, February
2021, https:/www.wilsoncenter.org/sites/ default/files/media/uploads/documents/U ncommon $\% 20$ Cause $\% 20-\% 20$ The $\% 20 \mathrm{Fu}$ ture\%20of\%20the\%20OSCE\%20v2.pdf

8 Ibid 


\title{
Russia and the OSCE
}

\author{
Andrei Zagorski
}

\section{Abstract}

For years, Moscow has criticized the OSCE with a view to limiting the Organization's operations in the post-Soviet area. At the same time, Moscow has not given up on the Organization. Russia's agenda for the OSCE includes revisiting its geographic and thematic priorities and transforming the OSCE into a treaty-based organization. Reviving a sense of common purpose would require a complex negotiation that could not avoid addressing principled Russian positions. Therefore, agreeing on a new status quo may appear premature today, but this should not exclude an agreement on a modus vivendi. This could be done by launching a "Helsinki+50" process that would include, in particular, the consideration of a constituent document, reconciliation of the freedom of alliances with the concept of the indivisibility of security, and revisiting the principles of freedom of the media and non-intervention. The OSCE should seek to increase the common ground between participating States by expanding its activities in the least controversial fields, such as countering transnational threats or addressing the consequences of the coronavirus pandemic.

\section{Introduction}

There is at least one thing worse than working through the OSCE - and that is working without the OSCE. Churchill's expression, rephrased for the topic at hand, captures Russian debates over the OSCE. In short, Moscow is strong enough to prevent the OSCE from doing what it considers unwelcome yet too weak to bend the OSCE to its own agenda. Therefore, Moscow has for years

\section{* Andrei Zagorski}

Primakov National Research Institute of World Economy and International Relations (IMEMO), Russian Academy of Sciences zagorskiandrei@gmail.com sought to hold the OSCE captive by insisting on a strict application of the consensus rule.

This does not mean, however, that Russia is ready to abandon the OSCE. On the contrary, Russian foreign affairs ministers are among the few who are consistently present at the annual Ministerial Council meetings. In addition, the OSCE is occasionally seen as one of the few institutions available to Russia for limiting the damage resulting from the deteriorating relationship between Russia and the West. This was particularly evident in the early phases of the Ukraine crisis. Russia also continues to appreciate the cooperation among the Co-Chairs of the Minsk Group, despite the Group's failure 
to terminate the war between Armenia and Azerbaijan over Nagorno-Karabakh in 2020 and the uncertainty regarding its role in managing the conflict.

The Russian Federation's difficult relationship with and within the OSCE has deep roots in the lost sense of common purpose among the participating States, manifested in continuous controversies over the OSCE's thematic and geographic priorities in general, and its structures and institutions in particular.

The first part of this paper focuses on Russian criticism of the OSCE and on what Moscow does not want the OSCE to do. The second part examines the agenda pursued by Russia within the OSCE and presents what Moscow expects from the Organization. The paper concludes with policy recommendations on how to reduce the gap in the definition of common purpose, at least in the mid term.

\section{Criticism of the OSCE}

Russia's criticism of the OSCE has a long history. In 1999, during the NATO air strikes in Yugoslavia, it accused the OSCE not only of being unable to enforce its principles, but also of having served as a cloak for the operation. ${ }^{1}$ Tensions grew further with the second Russian war in Chechnya, which began later in 1999 and led to the closure of the OSCE Assistance Group in Chechnya in 2003, and with the critical observation by the OSCE Office for Democratic Institutions and Human Rights (ODIHR) of Russian elections since 2003. Also, against the backdrop of the "colour revolutions" in
Eastern Europe, the OSCE was seen as an agent of the "regime changes" that Moscow sought to prevent in its neighbourhood.

Concerns were raised in Moscow that a NATO-dominated European security order would reduce the role of the OSCE to "democratizing" the "European periphery" and that the prioritization of the operational activities of "excessively autonomous" OSCE institutions would shift the balance away from political consensus-building. ${ }^{2}$ In this context, the thesis of geographic and thematic imbalances in OSCE activities was put forward, especially with regard to activities "east of Vienna" regarding the human dimension. ${ }^{3}$ Ever since, emphasizing the need to prioritize political dialogue, rebalancing OSCE activities and reducing the autonomy of its institutions have remained central to Russia's OSCE policy. In 2004, the Bulgarian Chair suggested shifting the focus of the activities of the Organization from East-Central and South-Eastern Europe to the thus far modest OSCE presence and activities in the post-Soviet space, particularly in Central Asia and the South Caucasus. This was exactly what Russia, supported by a minority group of participating States, primarily the members of the Collective Security Treaty Organization (CSTO), did not want the OSCE to do.

The highly controversial debate at the Sofia Ministerial Council in December 2004 opened a discussion about reforming the OSCE, which remains inconclusive to this day. Moscow views the OSCE critically as an organization that facilitates US, EU, and NATO intervention 
into the domestic affairs of states, particularly post-Soviet states, with the aim of imposing Western-style political regimes and installing pro-Western governments. ${ }^{4}$ President Vladimir Putin has voiced this criticism as follows: "We see constant attempts to turn the OSCE, a crucial mechanism for ensuring common European and also trans-Atlantic security, into an instrument in the service of someone's foreign policy interests. The result is that this very important organization has been hollowed out."5 Russia's demand for a rebalancing of the OSCE's work does not mean that it believes the Organization should expand its activities "west of Vienna". Rather, Russia maintains that the OSCE should reduce its buman $d i$ mension-related activities in the post-Soviet area. Whether or not the latter should be reduced or, at the least, remain at their previous level was one of the most controversial issues discussed within the first OSCE Panel of Eminent Persons in $2005 .^{6}$

Since Moscow did not succeed in imposing its reform agenda for the OSCE either in 2004 or thereafter, it began systematically hijacking the Organization by insisting on a rigid application of the principle of consensus and by being more assertive in the discussion of the OSCE budget. Apart from this, Moscow and a number of other post-Soviet states pursued a policy of unilaterally restricting OSCE activities by calling into question ODIHR's methods of election observation, downgrading or terminating OSCE presences, or otherwise limiting activities in individual countries. Russia's general philosophy was that the OSCE should be responsive to requests from host governments rather than pursuing its own agen$\mathrm{da}$, which it perceived as a Western one. It believed that it should not be the participating States who follow the recommendations of the OSCE institutions, but rather the OSCE institutions who adapt their policies to criticism from the participating States. ${ }^{7}$

\section{Russia's agenda for the OSCE}

The Russian agenda for the OSCE has remained consistent over the past decades. It can be summed up in three clusters: resuming substantive political dialogue, reforming the Organization, and redefining priority areas for OSCE activities.

\section{Resuming substantive dialogue}

Resuming substantive dialogue within the OSCE (as well as with NATO and the EU) without preconditions is the main point currently on the Russian agenda with respect to these organizations. Russia's expectation is that such dialogue should take into account Russia's concerns and lead to progress on issues that it has put forward for many years. These include confirming the indivisibility of security as opposed to the freedom of alliances and addressing the need to "rebalance" OSCE activities and to reform the Organization, including by depriving its institutions of their "excessive autonomy". The hope is that this dialogue would enable Russia and the West to find 
common ground based on a reasonable compromise, resulting in "a new agenda, focusing on what unites rather than separates us", as formulated by Russian Foreign Minister Sergey Lavrov (emphasis added). ${ }^{8}$

The OSCE's "Helsinki+40" dialogue in 2013 and 2014 was seen in Moscow as a promising exercise that could lead to adjustments in OSCE operations. It was interrupted, however, by the Ukraine crisis. Moscow would welcome resuming this exercise as a "Helsinki+50" dialogue process that would aim for a substantive agreement on the OSCE agenda and priorities to be adopted in 2025 at a high-level meeting on the $50^{\text {th }}$ anniversary of the Helsinki Final Act. However, few if any Russian officials believe this would be feasible under the current circumstances. ${ }^{9}$

\section{Reforming the OSCE}

Russia has advanced proposals for the transformation of the OSCE into a treatybased international organization since 2004. According to these proposals, participating States would take part in the organization's discussions in their individual capacity rather than as part of any group of countries. Autonomous OSCE institutions and structures would be integrated into the Secretariat. Their activities would be subject to consensus and strictly follow political guidance from the OSCE decision-making bodies. Election observation would be governed by a detailed set of standards. At the core of these proposals is the adoption of a charter or constituent document that would govern the operation of the OSCE executive institutions and structures. ${ }^{10} \mathrm{Al}$ though all discussions on the Russian proposals have stalled, the country is continuing its efforts in this regard. At the 2020 Ministerial Council meeting in Tirana, Foreign Minister Lavrov pushed again for reform and suggested the establishment of a respective informal working group. ${ }^{11}$ In February 2021, he provided the OSCE Chairperson-in-Office, Swedish Foreign Affairs Minister Ann Linde, with a food for thought paper on the issue. ${ }^{12}$

\section{Redefining priority areas ${ }^{13}$}

Moscow's proposals for specific areas in which the OSCE participating States should seek to cooperate include transnationals threats, such as countering terrorism and illegal drug trafficking, threats generated by information and communication technologies, human trafficking, and other forms of organized crime. Russia also expects the OSCE to contribute to overcoming the consequences of the coronavirus pandemic. In particular, Russia has suggested that the Office of the Coordinator of OSCE Economic and Environmental Activities be tasked with strengthening scientific and technological cooperation in the medical and health fields. ${ }^{14}$

While the issues related to transnational threats are relatively uncontroversial within the OSCE, other Russian priorities concern issues that are at the centre of the rhetorical confrontation between Russia and the West. One example is 
the protection of the rights of national minorities. Russia puts the emphasis on the linguistic and educational rights of the Russian minorities in Ukraine and the Baltic states and on the promotion of social and economic, as opposed to political and civil, rights. While supporting the discussion on freedom of information, Moscow puts emphasis on the need to counter restrictions on Russian media outlets and journalists in Ukraine and in the West. Moscow remains critical of OSCE activities in the human dimension, claiming that they are not only politically biased but also obsolete, particularly since all participating States are members of the UN and hence included in the work of its Human Rights Council. Furthermore, the majority of participating States are also members of the Council of Europe and are covered by its intrusive mechanism for the defence of human rights. These are among the reasons Russia cites to support its longstanding policy that the OSCE should reduce its human dimension activities, particularly in the post-Soviet countries, rather than expand them in the West.

Regarding the conflict cycle, the Russian approach is that every OSCE activity should be negotiated on a case-bycase basis, decided by consensus within the Permanent Council and subject to host nation consent. Otherwise, Moscow will seek to maintain the status quo in the conflicts under discussion. Moscow expects the OSCE to contribute to the implementation and consolidation of the Russia-brokered ceasefire in NagornoKarabakh. It also welcomes the OSCE's participation in the Geneva International
Discussions involving Georgia, Abkhazia, and South Ossetia. It sees the need to maintain the recent dynamic in the " $5+2$ " negotiations on the conflict concerning Transdniestria (Moldova). Moscow emphasizes that the OSCE should put more consistent pressure on Ukraine in order to motivate it to implement the Minsk agreements on resolving the conflict in the east of the country. ${ }^{15}$

The OSCE remains below the Russian radar as far as security in Central Asia is concerned, specifically the risks of spreading terrorism, narcotics trafficking, and regional destabilization emanating from Afghanistan. These risks are addressed through a net of bilateral and multilateral consultations involving relevant actors such as the US, China, Pakistan, India, Iran, the Central Asian states, and local actors in Afghanistan itself, including the Taliban. At the same time, Russia is strengthening its cooperation within the CSTO as a hedge against possible spillover effects of the Taliban taking over in Afghanistan. In this context, it expects the OSCE to further develop its institutional cooperation with the CSTO.

Russia has traditionally emphasized the importance of the economic dimension of the OSCE. Besides engaging in the discussion of the topic of connectivity, which has recently been put on the OSCE agenda, it has put forward the need for the OSCE to facilitate synergy between different integration processes in the OSCE area (e.g. between the EU and the Eurasian Economic Union) and the development of a "wider Eurasian Partnership". 
Russia engages in the debates on politico-military issues within the OSCE Forum for Security Cooperation, such as, inter alia, the growing military activities along the common border between Russia and NATO. However, Moscow proceeds on the basis that conventional arms control is a subject for Russia-NATO discussions rather than for the OSCE. Any further modernization of the OSCE Vienna Document on Confidence- and Security-Building Measures can, in Russia's view, only be considered after NATO has stopped expanding and has reversed activities on its eastern flank. ${ }^{16}$

\section{Recommendations}

Establishing a common denominator and reinventing a sense of common purpose within the OSCE would require complex negotiation between Russia and the West. Such negotiation, in order to have a chance of leading to a solid arrangement with Russia, could not avoid addressing principled questions put forward by the latter, such as on the indivisibility of security. It would involve sensitive issues, including the role of the OSCE's human dimension, and the relatively autonomous status of OSCE institutions. It does not currently appear plausible that the conditions for such a negotiation exist. Nevertheless, even though agreeing on a new status quo may appear premature today, this should not prevent an agreement on a modus vivendi that could hold for the time to come.

The current Russian position should not be taken entirely at face value. Many of the Russian Federation's statements, particularly on specific issues, seem to be part of the rhetorical confrontation that is being waged within the OSCE. The limits of a possible compromise, however, can only be explored when substantive dialogue is resumed. This is why, despite the widespread scepticism, it is worth considering taking the forthcoming $50^{\text {th }}$ anniversary of the Helsinki Final Act as an occasion for launching a "Helsin$k i+50$ " dialogue. Its purpose would be to produce an agreement on a common purpose for the OSCE for the years to come. It should include continued discussion on the adoption of a constituent document of the OSCE, which would transform it into a treaty-based organization and pave the way for the signing of the convention on the legal personality of the OSCE that participating States have negotiated. Such a document should include an agreement on the modus operandi of the OSCE institutions, which from a Russian perspective should not exceed their current level of autonomy. Reconciling the freedom of alliances with another OSCE commitment to respect the legitimate worries of the states concerned (or the "indivisibility of security") is another principled issue to be addressed within such a dialogue.

A Helskini +50 dialogue should include issues which are controversial but represent matters of concern for both Russia and the West. The OSCE could revisit and further specify its provisions concerning the freedom of the media and access to information. Both Russia and the West believe that they currently find themselves in the midst of an information war using new digital technologies and social 
networks. As freedom of information is closely linked to the debate over the possibility of intervening in domestic affairs by means of new information technologies, the OSCE participating States should also be encouraged to revisit and update the principle of non-intervention.

In conclusion, from a Russian perspective, the OSCE would do well to increase the common ground between participating States by expanding its activities in the least controversial areas of cooperation, even if they do not address the most principled issues. Countering transnational threats and addressing the consequences of the coronavirus pandemic are the most obvious fields where this could be undertaken.

\section{Notes}

Alexander Matveev, "The OSCE Identity Crisis”, in: IFSH (ed.), OSCE Yearbook 1999, Baden-Baden: Nomos, 2000, 59-78.

Mikhail Petrakov, "The Role of the OSCE from a Russian Point of View", in: IFSH (ed.), OSCE Yearbook 2000, BadenBaden: Nomos, 2001, 53-61.

Alexander N. Alexeev, "The Future of the OSCE: Russia's Version”, in: Daniel Warner/Valérie Clerc (eds.), Challenges Faced by the OSCE During 2001, Geneva: The Graduate Institute of International Studies, 2002, 151-166.

Sergey A. Kostin, "Реформирование ОБСЕ - необходимое условие для дальнейшего существования организации" [OSCE Reform - A Necessary Provision for Further Existence of the Organization], in: Pravo I bezopasnost' 1-2/2013, 100-107, p. 106; Lev S. Voronkov, “ОБСЕ и европейская безопасность. Что дальше?” [OSCE and European Security: What Next?], in:
Sovremennaya Evropa 1/2018, 69-79, pp. $73 \mathrm{f}$.

5 Statement by President of Russia Vladimir Putin, "Meeting of the Valdai International Discussion Club", Official Internet Resources of the President of Russia, 27 October 2016, en.kremlin.ru/events/president/news/53151

Author's conversations with the members of the Panel in 2005.

“О предстоящем рабочем визите в Россию Министра иностранных дел Швеции, Действующего председателя ОБСЕ А. Линде” [On the forthcoming working visit to Russia of the Minister for Foreign Affairs of Sweden, OSCE Chairperson-in-Office A. Linde], Ministry of Foreign Affairs of the Russian Federation, 1 February 2021, https://www.mid.r $\mathrm{u} / \mathrm{ru} /$ foreign_policy/rso/osce/-/asset_publi sher/bzhxR3zkq2H5/content/id/4546081

8 "Foreign Minister Sergey Lavrov's statement at the meeting of the OSCE Ministerial Council, 3 December 2020", Ministry of Foreign Affairs of the Russian Federation, 3 December 2020, https://w ww.mid.ru/en/web/guest/foreign_policy/ rso/osce/-/asset_publisher/bzhxR3zkq2H5 /content/id/4465649

9 Remarks by a senior Russian MFA official in a Russo-German dialogue in April 2021.

10 Andrei Zagorski, "Make the OSCE Institutions Less Dependent on Politics, Not More", in: Helsinki Monitor 3/2005, 209-213.

11 "Foreign Minister Sergey Lavrov's statement", cited above (Note 8).

12 "Foreign Minister Sergey Lavrov's remarks and answers to questions at a joint news conference following talks with OSCE Chairperson-in-Office, Minister of Foreign Affairs of Sweden, Ann Linde, Moscow, February 2, 2021”, Ministry of Foreign Affairs of the Russian Federation, 2 February 2021, https://ww w.mid.ru/en/web/guest/obycnye-vooruze 
nia/-/asset_publisher/MlJdOT56NKIk/co ntent/id/4550431

13 Unless otherwise specified, based on: "Foreign Minister Sergey Lavrov's statement", cited above (Note 8); "Foreign Minister Sergey Lavrov's remarks and answers", cited above (Note 12); "On the forthcoming working visit”, cited above (Note 7).

14 Alexander Lukashevich, Statement by Mr. Alexander Lukashevich, Permanent Representative of the Russian Federation, at the $1305^{\text {th }}$ Meeting of the OSCE Permanent Council via Video Teleconference, 11 March 2021, PC.DEL/313/21, 11 March 2021, pp. 2-3, https://www.osce.or $\mathrm{g} /$ files/f/documents/b/e/482352.pdf

"Выступление Постоянного представителя Российской Федерации А.К.Лукашевича на заседании Постоянного совета ОБСЕ, 15 июля 2021 года" [Statement by the Permanent Representative of the Russian Federation A. K. Lukashevich at the meeting of the OSCE Permanent Council, 15 July 2021],
Ministry of Foreign Affairs of the Russian Federation, 16 July 2021, https://www.mi d.ru/ru/foreign_policy/rso/osce/-/asset_pu blisher/bzhxR3zkq2H5/content/id/48148 57

“Выступление руководителя Делегации Российской Федерации на переговорах в Вене по вопросам военной безопасности и контроля над вооружениями К.Ю.Гаврилова на 967-м пленарном заседании Форума ОБСЕ по сотрудничеству в области безопасности, Вена, 3 февраля 2021 года” [Statement by the Head of the Delegation of the Russian Federation to the Vienna negotiations on military security and arms control K. Y. Gavrilov in the $967^{\text {th }}$ Plenary Meeting of the OSCE Forum for Security Cooperation, Vienna, 3 February 2021], Ministry of Foreign Affairs of the Russian Federation, 4 February 2021, https://ww w.mid.ru/ru/foreign_policy/rso/osce/-/ass et_publisher/bzhxR3zkq2H5/content/id/ 4552424 


\title{
France and the OSCE
}

\author{
Barbara Kunz"
}

\section{Abstract}

This paper provides an overview of France's role within the OSCE and the part the latter plays in French foreign policy. It shows that France is most engaged in the OSCE's first, politico-military dimension, in particular in the context of conflict resolution in the OSCE area. The third, human dimension is a further French priority. On the whole, however, France's engagement in the OSCE does not figure strongly with regard to its overall ambition to play an important part in global affairs. French foreign policymakers do not consider the OSCE a key forum, capable of rapidly achieving political results for France. While Paris continues to stress its attachment to multilateralism in its declaratory foreign policy, it is not eager for the OSCE to become an actor in its own right. France is therefore also opposed to increasing the Organization's funding. In light of France's longstanding foreign and security priorities, it is unlikely that its approach to the OSCE will change in the foreseeable future.

\section{Introduction}

Although France initially needed convincing to support the establishment of a Conference on Security and Co-operation in Europe (CSCE), later renamed the OSCE, it eventually came to play an important role in the Organization. The Paris Charter was famously signed in the French capital in 1990, and the government successfully placed French nationals in top OSCE positions. From 2005 to 2011, French diplomat Marc Perrin de Brichambaut served as Secretary General. From 2017 to 2020, former French Mi-

* Barbara Kunz

Institute for Peace Research and Security Policy at the University of Hamburg (IFSH) kunz@ifsh.de nister of European Affairs Harlem Désir served as the OSCE Representative on Freedom of the Media.

Today, France is engaged in the dayto-day operations of the OSCE. It sends observers to all election monitoring missions, and several dozen French nationals work at the Secretariat and other OSCE bodies. France's engagement is even more apparent in the context of conflict resolution in the OSCE area, with the country playing a role in both Nagorno-Karabakh and the conflict in and around Ukraine. In communication with the OSCE, France was also deeply engaged in mediating the conflict in Georgia in 2008.

At the same time, however, France can hardly be described as a true driving force within the Organization. Its actions in 
the OSCE fall short of being commensurate with its ambitions regarding its role in Europe and the world. Likewise, the OSCE remains largely absent in French foreign policy debates - despite the fact that a number of OSCE topics are also French foreign policy priorities, ranging from big picture geopolitics to more technical matters. For instance, the OSCE is entirely absent from the Actualisation stratégique, France's strategy document published in February 2021. ${ }^{1}$

This paper takes a closer look at France's role in the OSCE in the context of more general tendencies in French foreign and security policy. It first describes France's actions in the OSCE and then considers the OSCE's role in pursuing French foreign policy objectives. It concludes that the OSCE's added value is not always obvious to France, which explains why it is not an impetus provider in the Organization and does not consider the OSCE a key forum for pursuing its foreign policy priorities.

\section{Mediation of protracted conflicts}

The first dimension, and conflict resolution in particular, is a key area of France's engagement in the OSCE. This is also the area that receives the most attention in the country. France has played a role in attempts to resolve two key conflicts in the OSCE region: the conflict over Nagorno-Karabakh between Armenia and Azerbaijan and the conflict in and around Ukraine. In terms of the former, France co-chairs the Minsk Group (along with the United States and Rus- sia), which is working toward a peaceful settlement of the conflict. ${ }^{2}$ After violence flared up in late 2020, a domestic debate on France's recognition of NagornoKarabakh as an independent state ensued. The two chambers of the French parliament voted in favour of a motion by the conservative party Les Républicains, which was primarily interested in supporting "Oriental Christians" - a relatively popular theme in France, notably on the right of the political spectrum. ${ }^{3}$ Rejecting the motion, France's government underscored its interest in continuing to co-chair the Minsk Group, which would be incompatible with the formal recognition of Nagorno-Karabakh. ${ }^{4}$ France has longstanding ties with Armenia, which is part of the Francophonie, notably due to the significant number of French citizens of Armenian descent. France has also officially recognized the Armenian genocide.

With perhaps even greater international visibility, France is one of the two "Western" members of the Normandy format (alongside Germany), which is aimed at finding a solution to the Ukraine conflict. French presidents and officials have participated in, and at times hosted, several high-profile summits, which resulted inter alia in the Minsk II agreement. ${ }^{5}$ In a narrower OSCE context, French diplomat Pierre Morel headed the sub-group on political affairs of the Trilateral Contact Group for the Peaceful Settlement of the Situation in Eastern Ukraine until June 2021. France also contributes to the OSCE Special Monitoring Mission to Ukraine, both financially and with personnel. 
Besides France's obvious interest in conflict resolution, its prominent role in the above-named formats also aligns with its self-perception as a relevant global actor. With a permanent seat on the UN Security Council, France and its diplomats believe in the necessity of playing a decisive role on the international stage and in high diplomacy. Both the Minsk Group and the Normandy format allow France to sit at the same table with other major powers, making engagement attractive from Paris's perspective.

\section{Human rights a priority}

In French foreign policy discourse, human rights always matter. This is linked to France's self-perception as the "country of human rights", shouldering a special responsibility for human rights that derives from the 1789 Declaration of the Rights of Man and of the Citizen. In addition to the first dimension activities mentioned above, many French undertakings consequently fall within the OSCE's third (human) dimension. Perhaps most noteworthy in the past year was France's support for triggering the Moscow Mechanism ${ }^{6}$ in the aftermath of Belarus's allegedly fraudulent 2020 presidential election, when the Belarusian regime repressed peaceful demonstrations and violated human rights. Following an initiative by the United Kingdom, France was one of seventeen participating States to invoke the Mechanism. ${ }^{7}$ In addition, France co-presides over the informal OSCE Group of Friends on the safety of journalists. ${ }^{8}$ Gender equality has also been an item on the agenda, notably in conjunction with the Generation Equality Forum held in Paris in the summer of 2021, where the OSCE pledged "to improve gender equality by taking action on Gender Based Violence, Economic Justice and Rights and Technology \& Innovation". 9 A further matter of importance to Paris is the fight against human trafficking. ${ }^{10}$

\section{Scepticism about the OSCE's added value}

These activities notwithstanding, the OSCE is not very high on France's agenda overall. This has arguably become more the case in recent years. Since Emmanuel Macron's accession to the French presidency, pragmatism has been a core element of French foreign and security policy, which has translated to less attention being paid to formats and institutional settings as compared to the policy objective at hand. A clear illustration of this is the relative decline in importance of "l'Europe de la Défense", the EU's Common Security and Defence Policy, the building and strengthening of which has been a longstanding French policy objective. Under Macron, the idea has largely been to do "whatever works" in flexible multi- and mini-lateral formats, for example in combatting terrorism in the Sahel region - one of France's key foreign and security policy endeavours.

It is against this backdrop that France's view of the OSCE must be understood. Although Paris has routinely underscored the importance of multilateralism and 
even co-founded the Alliance for Multilateralism with Germany, ${ }^{11}$ a significant part of recent French foreign policy is in fact characterized by unilateralist tendencies. ${ }^{12}$ France does not view the OSCE's standing as the only remaining pan-European security institution and multilateral platform as reason enough to invest in it, which sets the country apart from some of the most engaged participating States, in particular Germany and Switzerland. In addition, the OSCE does not cover the geographic area that most interests France. Until recently, Central Europe and Eastern Europe west of Russia mattered relatively little in French foreign policy thinking. France is traditionally more focused on Africa, the Middle East, and increasingly, the Indo-Pacific.

Moreover, in light of the OSCE's many difficulties, its added value is not clear to Paris. This pertains to the Organization's usefulness in ensuring European security and the fact that a key security challenge - the conflict with Russia and allied states - has been the main cause of the OSCE's difficulties. Paris rarely views the OSCE as the right vehicle for pursuing its own interests, and one area in which its scepticism clearly shows is its stance toward the Organization's budget: Paris views it as unfair that the bulk of OSCE funding comes from EU member states, the United States, Canada, Switzerland, and Norway. In 2018, France paid 14.6 million euros in mandatory contributions, toward a total budget of 138 million euros (to which voluntary contributions needed to be added, such as 7.6 million euros for the Special Monitoring Mission that same year). ${ }^{13}$ In 2019, France went as far as to block the Organization's budget on these grounds. ${ }^{14}$ In the context of adopting the 2020 unified budget, France recently reiterated that "it is not acceptable for 17 participating States alone to finance 99 per cent of the OSCE Budget." 15 In light of scarce financial resources for the country's foreign policy and in a general context of austerity in the wake of the Eurocrisis, ${ }^{16}$ Paris is an adamant defender of "zero nominal growth", i.e. not increasing the OSCE's budget. Given inflation, this in fact implies a commitment to shrinking the Organization's budget. ${ }^{17}$

France's reticence with regard to providing the OSCE with more funding must also be seen against the backdrop of its dissatisfaction with the Organization's governance. Paris indeed recognizes the need for greater efficiency. At the same time, however, it has little interest in the OSCE's becoming an actor in its own right, with its own strategies. This was illustrated, for instance, by France's scepticism vis-à-vis the creation of a small Strategic Policy Support Unit at the Secretariat under Secretary General Thomas Greminger, known for his ambitious approach to making the OSCE more relevant and strategic. France's preference is to keep the OSCE as intergovernmental as possible in order to avoid transferring power and "strategy making" to Vienna. The fact that Greminger was never officially received in Paris serves as yet another illustration of France's limited interest in the Organization.

France's overall diplomatic ambitions stand in contrast to the country's engagement in conflict resolution and its day-today business within the OSCE. French 
diplomacy publicly supports the OSCE, and France contributes to the Organization both financially and with (seconded) personnel. In this sense, it is a loyal participant, willing to do whatever it takes to keep the OSCE afloat. Yet, France is not interested in developing the Organization much further beyond the status quo, preferring to keep it as "intergovernmental" as possible.

\section{Paris lacks an "OSCE reflex"}

Rather unsurprisingly, therefore, France pursues most of its foreign and security policy objectives outside the OSCE, and the OSCE matters little - if at all - in French political debates. A striking illustration of this is the 2017 presidential campaign, in which several candidates from across the political spectrum called for a pan-European conference on security. Not one mentioned the OSCE. On a related subject, President Macron has spoken on several occasions of "revisiting" the European security architecture and the need to resume dialogue with Russia. ${ }^{18}$ France's purely bilateral "strategic dialogue" with Russia was launched in 2019. Inter alia, it includes meetings in a $2+2$ format, i.e. between the respective foreign and defence ministers. In addition, Macron named Pierre Vimont, one of France's most senior diplomats, to be "Special Envoy for the security and trust architecture with Russia". ${ }^{19}$ References and links to the OSCE are again absent in this initiative, although it pertains to its very essence. Fear of its being bogged down by intra-organizational disagreements and a general inability to deliver results - as is apparent in the Structured Dialogue, for instance - may have played a part in the decision not to place it in the OSCE context. Another explanation may simply be that the possibility did not occur to anyone, which would suggest that Paris lacks an "OSCE reflex": the OSCE may not even arise as a consideration in decisions on appropriate settings for pursuing France's interests.

Besides these major geopolitical matters, there are examples of more technical initiatives with an apparent OSCE connection that have not been linked to the Organization. One first dimension topic that France has continued to push within the OSCE is the fight against the trafficking of small arms and light weapons (SALW). France has also pursued initiatives on related matters that run parallel to OSCE initiatives, such as the FrancoGerman initiative on SALW in the Western Balkans. ${ }^{20}$ Despite the OSCE's own work on SALW, the Franco-German initiative was merely discussed at a side event at the 2018 Ministerial Council in Milan. ${ }^{21}$

In sum, France is not a driver of major initiatives within the OSCE; the role of impetus provider is generally left to Germany and Switzerland. In many cases, France follows along, such as when Germany suggested the Structured Dialogue in 2016, intended to relaunch conventional arms control in Europe. France is one of many likeminded countries calling for such a relaunch following the Steinmeier initiative. ${ }^{22}$ 
The way forward: Change seems unlikely

France has been reluctant to throw its diplomatic weight into the OSCE context. Within the OSCE, and with the exception of specific dossiers such as Ukraine, France's role is rarely commensurate with its self-image as a global power with a permanent seat on the UN Security Council. In a sense, the relationship between France and the OSCE can thus be characterized in terms of missed opportunities. It is regrettable, for example, that the $30^{\text {th }}$ anniversary of the Charter of Paris was not commemorated appropriately. The fact that the Organization found itself without leadership in the summer of 2020 and the pandemic may be to blame. Still, the Paris Charter's anniversary would have been an excellent occasion to underscore the relevance of a rules-based European security order. Likewise, the fact that Secretary General Thomas Greminger was not received by the French foreign minister is hard to interpret as anything other than an indication of disinterest. Perhaps a more encouraging sign, Greminger's successor, German diplomat Helga Schmid, met with France's Minister of State for European Affairs Clément Beaune and Foreign Minister Jean-Yves Le Drian in Paris in July 2021. ${ }^{23}$

France's activity in the OSCE is unlikely to evolve in the medium to long term. The main reason is that the Organization matters little in terms of the main foreign policy objectives and key challenges France has identified for itself and Europe. The 2021 Actualisation stratégique stresses jihadist terrorism, the spread of weapons of mass destruction, and the "return of strategic competition between great powers", ${ }^{24}$ the latter referring to the United States and China in particular. Overall, France clearly expects Europe's strategic environment to deteriorate further, and at a faster pace. This will likely lead future French presidents and governments to focus even more closely on the country's priorities - in terms of the allocation of funding and personnel, but also in terms of which diplomatic channels seem the most promising for promoting European security and French and European interests. The OSCE does not generally concern itself with these priorities, either functionally or geographically. It is therefore unrealistic to expect considerable changes to France's stance towards the OSCE.

\section{Notes}

1 See "Actualisation stratégique", French Ministry of the Armed Forces, February 2021, https:/www.defense.gouv.fr/dgris/ presentation/evenements/actualisation-str ategique-2021. An official English translation is available at the same address.

Note that the Minsk Group is not an OSCE institution properly speaking, although it has close ties to the Organization. The three Minsk Group Co-Chairs did not play a role in settling the 2020 Karabakh war. Thus far, France's ever more complicated relations with Turkey - which include dangerous situations involving military vessels in the Eastern Mediterranean in June 2020, as well as personal attacks on Emmanuel Macron by President Erdogan - seem not to 
have affected France's role in the Minsk Group.

For a brief introduction, see David Rich, "La cause des chrétiens d'Orient suscite de vives oppositions politiques en France”, France24, 5 March 2021, https:// www.france24.com/fr/moyen-orient/202 10305-d\%C3\%A9fense-des-chr\%C3\%A9ti ens-d-orient-la-cause-suscite-de-vives-oppo sitions-politiques-en-france

See Frédéric Senneville, "Pourquoi la France ne veut-elle pas reconnaître le Haut-Karabakh?", LCI, 4 December 2020, www.lci.fr/international/pourquoi-la-fran ce-ne-veut-pas-reconnaitre-le-haut-karaba kh-2171958.html

For details, see e.g. European Parliamentary Research Service, "At a glance: Ukraine: The Minsk agreement five years on", March 2020, https://www.europarl.e uropa.eu/RegData/etudes/ATAG/2020/64 6203/EPRS_ATA(2020)646203_EN.pdf

OSCE, Moscow Mechanism, 1 December 1991, amended 1993, https://www.osce.o rg/odihr/20066

7 Stephanie Liechtenstein, "Exclusive: Austrian professor nominated for OSCE mission to investigate human rights violations in Belarus", Security and Human Rights Monitor, 23 September 2020, https://www.shrmonitor.org/exclusive-no mination-austrian-professor-for-osce-miss ion-to-investigate-human-rights-violation s-in-belarus/

8 See the French OSCE representation's Twitter feed, https://twitter.com/RP_Fr ance_OSCE/status/1394670737051504 64 0/photo/1

"OSCE commits to new gender equality targets at Generation Equality Forum in Paris”, OSCE, 1 July 2021, https://www.o sce.org/secretariat/491506

"OSCE Special Representative commends France on prioritizing fight against trafficking and calls for strengthening victim-centred approaches”, OSCE,
2 July 2021, https://www.osce.org/cthb/4 91620

11 For more information, see the Alliance's website at https://multilateralism.org/

12 See e.g. Ronja Kempin (ed.), "France's foreign and security policy under President Macron", SWP Research Paper 2021/RP 04, May 2021, https://www.sw p-berlin.org/en/publication/frances-foreig $\mathrm{n}$-and-security-policy-under-president-ma cron/

13 "France's financial contribution to the OSCE”, French Foreign Ministry, https:// www.diplomatie.gouv.fr/en/french-foreig $\mathrm{n}$-policy/security-disarmament-and-non-p roliferation/our-alliances-and-cooperatio ns/france-and-the-osce/\#sommaire_4

14 Blaise Gauquelin, "La France bloque le budget 2019 de l'OSCE”, Le Monde, 8 January 2019, https://www.lemonde.fr/in ternational/article/2019/01/08/la-france-bl oque-le-budget-2019-de-1-osce_5406338_3 210.html

15 OSCE, Decision No. 1369, Approval of the 2020 Unified Budget, $1269^{\text {th }}$ Plenary Meeting, PC Journal $\mathrm{N}^{\circ} 1269$, Agenda item 6, PC.DEC/1369, 28 May 2020, Attachment 7, p. 2, https://www.osce.org/fil es/f/documents/4/4/453804.pdf

16 In recent years, the French foreign ministry's budget has suffered considerable cuts. From 2007 to 2020, it lost about 10 per cent of its personnel due to budget constraints and has seen its funding decrease every year up to the pandemic. See e.g. "France cuts billions from public spending to meet EU limit", BBC, $11 \mathrm{Ju}$ ly 2017, https://www.bbc.com/news/worl d-europe-40569589

17 Loïc Simonet, "Twenty Years after the Istanbul Platform for Co-operative Security: How Can the OSCE's Contribution to 'Effective Multilateralism' Be Strengthened through Co-operation with Other International and Regional Organizations?", in: IFSH (ed.), OSCE Year- 
book 2019, Baden-Baden: Nomos, 2020, 247-272.

18 Most prominently, see President Macron's speeches at the annual ambassador's conferences in August 2018 and 2019, respectively, https:/www.elysee.fr/ emmanuel-macron/2018/08/27/discours -du-president-de-la-republique-a-la-confer ence-des-ambassadeurs; https://www.elys ee.fr/emmanuel-macron/2019/08/27/disc ours-du-president-de-la-republique-a-la-co nference-des-ambassadeurs-1

19 For details, see Stephanie Liechtenstein, "If we want to defend Europe's interests, we have to engage with Russia" (interview with Pierre Vimont), Security and Human Rights Monitor, 14 April 2021, https://www.shrmonitor.org/if-we-want-t o-defend-europes-interests-we-have-to-eng age-with-russia-dialogue-with-russia/

20 See "Initiative franco-allemande sur la lutte contre les trafics illicites d'armes à feu dans les Balkans occidentaux", French Ministry of Foreign Affairs, https://www.diplomatie.gouv.fr/fr/poli tique-etrangere-de-la-france/securite-desar mement-et-non-proliferation/desarmeme nt-et-non-proliferation/elimination-et-ma itrise-des-armements-classiques/article/ini tiative-franco-allemande-sur-la-lutte-contr e-les-trafics-illicites-d-armes-a

21 "Franco-German roadmap for comprehensive control of small arms and light weapons discussed in side event at OSCE Ministerial Council in Milan”, OSCE, 7 December 2018, https:/www.osce.org/ch airmanship/405647

"Relaunching conventional arms control in Europe", German Federal Foreign Office, 25 November 2016, https://www.aus waertiges-amt.de/en/aussenpolitik/theme n/abruestung/161125-ruestungskontrolle/ 285652

23 See Secretary General Helga Schmid's Twitter feed, https://twitter.com/Helga Schmid_SG/status/141063056722220237 3 ? $s=20$

24 "Actualisation stratégique", cited above (Note 1), p. 14 (English version). 


\title{
Turkey and the OSCE
}

\author{
Giray Sadik*
}

Abstract

This paper presents Turkey's perception of the OSCE and its expectations of the Organization. It examines the relevance of the OSCE for Turkey's foreign and security policy, the OSCE's shortcomings from a Turkish perspective, and the Turkish government's priorities for engagement with the Organization. Turkey's primary interest in the OSCE is for it to become more effective in stabilizing crises in the country's immediate neighbourhood. Other priorities for Turkey are the fight against terrorism and transnational organized crime.

\section{Introduction}

Turkey has a unique geostrategic position in the OSCE area, bordering the Balkans, the Black Sea, the Caucasus, the Middle East, and the Mediterranean. This case study presents Turkey's perception of the OSCE and what it expects from the Organization. It first examines the relevance of the OSCE for Turkey's foreign and security policy, followed by a discussion of the OSCE's shortcomings from a Turkish perspective and an analysis of the Turkish government's priorities for engagement with the Organization. The paper concludes with recommendations for the future of the OSCE in light of Turkish government views.

* Giray Sadik

Ankara Yildirim Beyazit University gsadik@ybu.edu.tr

\section{The OSCE's relevance for Turkey's foreign and security policy}

Turkey was engaged in the CSCE/OSCE process from the start and remains an active participant. It supports the strengthening of the OSCE's role, particularly in its immediate neighbourhood, where challenges include managing undocumented migration flows and regional conflicts such as those in Syria and Libya, with lingering repercussions for the Eastern Mediterranean. Such challenges are increasingly hybrid in nature, with the lines between national and international, civilian and military, and physical and cyber security becoming more and more blurred.

Turkey joined NATO and the Council of Europe in the early years of the Cold War. These organizations were and are likely to remain the anchor points for the country's connection to the West. Turkey therefore supports synergies and 
complementarity between these Western political and military organizations and the OSCE, in line with its policy of effective multilateralism.

Turkey considers the OSCE and the Council of Europe to have a special relationship and views them as working in tandem. Turkey's former Permanent Representative to the OSCE, Ambassador Rauf Engin Soysal, highlights the advantages of close cooperation between them as follows:

International organizations active in the same area - here I use the term "area" to denote both the geographical and conceptual area - do not per se stand in competition. On the contrary, positive overlaps and spill-overs can mutually reinforce their work. Therefore, we commend the efforts to strengthen the dialogue and institutional cooperation between the OSCE and the Council of Europe. Synergies at the organizations' executive as well as technical levels can increase the effectiveness of multilateralism. $^{1}$

A particular focus has been synergies in the areas of fighting terrorism and combating human trafficking. Turkey attaches importance to the OSCE's support of the implementation of the Additional Protocol to the Council of Europe Convention on the Prevention of Terrorism, the first international treaty addressing the phenomenon of foreign terrorist fighters. Turkey has ratified the Additional Protocol, and it entered into force in Turkey on 1 June $2018 .^{2}$
Relations with the EU are another important, if not unproblematic, element of Turkey's ties to the West. The OSCE provides Turkey with a good platform for approaching the EU, as it has been a participating State from the beginning, whereas its accession to the EU remains uncertain. At the same time, this uncertainty has a detrimental effect on Turkey's multilateral cooperation within the OSCE. There is always the risk that some EU state might decide to divert debate on an issue that is critical for Turkey to the EU arena, where the country is not represented.

\section{Turkey's expectations of the OSCE}

Turkey regards respect for the fundamental principles of the OSCE, particularly the affirmation of a close connection between security and cooperation and the consensus-based mode of operation, as essential for a strong OSCE that has added value for participating States' security.

Turkey's support for OSCE engagement in resolving protracted conflicts and its chairing of the Forum for Security Co-operation (FSC) in 2020 demonstrate its readiness to contribute to OSCE efforts to strengthen security and stability in its first, politico-military dimension. ${ }^{3}$ Turkey has emphasized the need to enhance the FSC's role as a unique platform for cooperation and confidence building.

Countering terrorism and other transnational forms of crime, which continue to threaten the OSCE region and its neighbourhood, has been an important thematic focus for Turkey. It has underscored the need to "collectively 
fight not only the Islamic State, but also other terrorist organizations with equal and ever-increasing determination without distinctions". ${ }^{4}$ Turkey perceives the equal and non-discriminatory application of standards by the OSCE in the fight against terrorism and other threats, from transnational organized crime to xenophobia and Islamophobia, as an essential aspect of the indivisibility of security in the OSCE area.

Turkey has been increasingly concerned about OSCE activities in its immediate neighbourhood and their potential impact on its security. In Turkey's view, the participating States need to lead by example when it comes to empowering the OSCE to resolve conflicts in the region. Turkey is involved in the joint Russian-Turkish monitoring of the ceasefire in the conflict over Nagorno-Karabakh and supports Azerbaijan's de-mining of the area.

Turkey believes it is important to deepen its relations with the OSCE's Mediterranean and Asian partner states and to further explore potential areas for cooperation. Turkey's rapprochement with the Mediterranean partners, especially recent diplomatic overtures to Egypt and Tunisia, can be attributed to the country's search for support from the region with respect to the crises in Libya and the Eastern Mediterranean. As for the Asian partners, Turkey's efforts are geared more towards economic cooperation with the advanced economies of the region, such as Japan, Korea, and Australia.

Regarding human security, Turkey believes the Office of Democratic Institutions and Human Rights (ODIHR) needs strengthening in the areas of reporting hate crime and integrating migrants. ${ }^{5} \mathrm{It}$ maintains that the OSCE should set an example for other forums in highlighting the threat of hate speech and racial and religious discrimination. It has emphasized the importance of achieving deliverables on tolerance and non-discrimination towards Muslims.

\section{Shortcomings of the OSCE from Turkey's perspective}

Turkey's main area of dissatisfaction with the OSCE concerns what it perceives as its application of double standards, particularly with regard to combating populism and xenophobia. Although secular by constitution, Turkey, whose population is predominantly Muslim, has a substantial diaspora in many of the OSCE participating States in Europe, the majority in Germany. Growing Islamophobia and racism and a surge of attacks against Turks in Europe have made tackling right-wing extremism in Europe an issue of direct concern for Turkey. ${ }^{6}$ Turkey expects full cooperation from the OSCE and its participating States in preventing such attacks and prosecuting their perpetrators. However, cooperation on this issue remains extremely limited at best, and this is likely to further plague Turkey's relations with the Organization.

Protracted conflicts pose another challenge to achieving stability in the OSCE area. The mere containment of protracted conflicts cannot be viewed as success. Turkey believes that the OSCE should be more active in its efforts to 
resolve these conflicts, making the best possible use of its broad acquis, tools, and capabilities. ${ }^{7}$ Turkey's dissatisfaction primarily concerns the OSCE Minsk Group's inability to end the conflict in Nagorno-Karabakh and the extensive use of banned landmines.

Finally, the Turkish government regards the cooperation of NGOs with the OSCE with scepticism. The participation of certain Turkish non-governmental organizations in OSCE events has been the subject of repeated disputes between Turkey and the Organization in recent years. The Turkish government has expressed the concern that some of the NGOs claiming to represent civil society are affiliated with terrorist organizations. Turkey insists that the OSCE should not provide a platform for terroraffiliated entities. Accordingly, Turkey expects the provisions of the 1992 Helsinki Document on the increased involvement of non-governmental organizations in OSCE activities to be fully implemented, especially the clause excluding their application to persons or organizations who publicly condone terrorism or the use of violence. ${ }^{8}$

\section{Outlook}

Turkey's key interest in cooperating with the OSCE and other international organizations is the protection of its national security. Dormant and active conflicts in the country's immediate neighbourhood from the Eastern Mediterranean to the Middle East and the Caucasus make the attainment of regional stability a priority.
Going forward, Turkey maintains that the OSCE must continue to play a key role in upholding the cornerstones of the European security architecture. To regain strategic relevance, the OSCE must respond to developments in the field in a timely manner. Support for initiatives such as the establishment of the Turkish-Russian ceasefire monitoring centre for Nagorno-Karabakh in the Aghdam district of Azerbaijan could pave the way for such renewed engagement.

There are further ways in which participating States - including Turkey - could help to enhance the OSCE's role. First, governments should maintain the OSCE as the preferred platform for negotiations and conflict resolution efforts where possible. Given that Turkey is still an EU candidate country, the OSCE is better positioned than the EU to mediate disputes between EU members and Turkey, as it is more inclusive and can therefore be expected to take a more neutral position.

Second, there is a need for a pragmatic approach to the interrelation between the three dimensions of the OSCE. A degree of compartmentalization may be necessary. As German Chancellor Merkel noted, "strategic ties with Turkey should be maintained despite serious differences on human rights." ${ }^{9}$ Recently, the EU adopted a similar approach with Hungary and Poland.

As one of the founding members of the OSCE, Turkey also needs to expand its level of engagement to include the second and third dimensions more comprehensively. To this end, Turkish academics and civil society should be encouraged to engage with OSCE-related issues on 
the national and international level. This would serve two major purposes. First, it could foster the admittedly hitherto limited engagement of civil society and academia with the OSCE, and thus promote Turkish perspectives internationally. Second, the work of civil society and academia could encourage Turkish foreign policymaking to be more multifaceted when considering the issues that the OSCE needs to address. In the face of challenges to the security of states and citizens, academia and civil society have the potential to become the new drivers of the OSCE agenda, especially in areas related to the human dimension.

\section{Notes}

Statement by Ambassador Rauf Engin Soysal, Permanent Representative of Turkey, in response to H.E. Marija Pejčinović Burić, Deputy Prime Minister and Minister of Foreign and European Affairs of Croatia and Chair of the Committee of Ministers of the Council of Europe, $1189^{\text {th }}$ Meeting of the Permanent Council, 14 June 2018.

2 Ibid.

3 Statement by Ambassador Rauf Engin Soysal, Permanent Representative of Turkey, in Response to $\mathrm{Mr}$ George Tsereteli, President of the OSCE PA, $1255^{\text {th }}$ Meeting of the Permanent Council, 16 January 2020.
$4 \quad$ Statement by Ambassador Rauf Engin Soysal, Permanent Representative of Turkey, in response to the Minister of Foreign and European Affairs of Slovakia, H.E. Miroslav Lajčák, $1211^{\text {th }}$ Special Meeting of the Permanent Council, 10 January 2019.

5 Statement by Ambassador Rauf Engin Soysal, Permanent Representative of Turkey, in Response to the Secretary General's Presentation of the 2021 OSCE Programme Outline, $1266^{\text {th }}$ Meeting of the Permanent Council, 7 May 2020.

6 Statement by Ambassador Rauf Engin Soysal, cited above (Note 3 ).

7 Ibid.

8 "The participating States will provide opportunities for the increased involvement of non-governmental organizations in CSCE activities. [...] The above provisions [on increasing the openness of CSCE activities, promoting understanding of the CSCE, expanding the role of NGOs] will not be applied to persons or organizations which resort to the use of violence or publicly condone terrorism or the use of violence." OSCE, Helsinki Document 1992 "The Challenges of Change”, 10 July 1992, Chapter IV, paras. 14 and 16, https://www.osce.org/ $\mathrm{mc} / 39530$

"Merkel says strategic ties with Turkey should be maintained despite 'serious differences on human rights", DuvarEnglish, 24 June 2021, https://www.duv arenglish.com/merkel-says-strategic-ties -with-turkey-should-be-maintained-despit e-serious-differences-on-human-rights-ne ws-57944 


\title{
Kazakhstan and the OSCE
}

\author{
Rustam Burnashev and Irina Chernykh"
}

\section{Abstract}

Since Kazakhstan joined the OSCE in 1992, its attitude towards the Organization has changed from full acceptance of its principles to a departure from them, especially with respect to its human dimension. This paper discusses the relevance of the OSCE for Kazakhstan, Kazakhstan's expectations of the OSCE, and its criticism of its work. It shows that while Kazakhstan identifies cooperation with the OSCE as one of its foreign policy priorities, it does not perceive the Organization as a key institution. Rather, it sees it as one of a number of European and Eurasian organizations in which it is only marginally involved and which therefore remain "external" to Kazakhstan. While participation in the OSCE and its development is regularly mentioned in Kazakhstan's political discourse, attention to the Organization is ad hoc. Kazakhstan tends to use the OSCE as a platform for its branding diplomacy, for example by highlighting the achievement of its 2010 Chairpersonship or by lobbying for the establishment of an OSCE thematic centre on sustainable connectivity in Nur-Sultan.

\section{Introduction}

Kazakhstan became a participant of the CSCE (since 1995 the OSCE) in 1992, after the collapse of the Soviet Union. Since then, its attitude towards the Organization has undergone significant transformation. In the 1990s, it tried to implement the basic principles of the CSCE/ OSCE, first and foremost the precept that "security is no longer based on the balancing of mutual threats but instead re-

\footnotetext{
* Rustam Burnashev

Kazakh-German University

burnashev@hotmail.com

Irina Chernykh

Kazakh-German University

chernykhi@yahoo.com
}

lies on the establishment of mutual confidence through openness and transparency." ${ }^{1}$ By the beginning of the 2000s, however, Kazakhstan had already distanced itself from the OSCE's principles, especially those of the human dimension. This was due in part to the sharp decline in trust and cooperation between Western and Eastern participating States in the late 1990s, and in part to the increase in authoritarianism in Kazakhstan and other post-Soviet states. At about the same time, Kazakhstan began to promote the idea of holding the OSCE Chair. Preparing the ground for Kazakhstan's assumption of this role became central to its "Path to Europe" programme, through which it aimed to achieve relations with leading European countries on "the lev- 
el of strategic partnership". ${ }^{2}$ Kazakhstan's 2010 OSCE Chairpersonship and the OSCE Summit it hosted in Astana did not overcome the crisis of the Organization, nor did they change the nature of the political regime in Kazakhstan and its attitude towards OSCE principles. For Kazakhstan, both the Chairpersonship and the Summit were important not so much for their content but rather as part of its branding diplomacy. Subsequent years have been marked by a relative decline in both Kazakhstan's engagement in the OSCE and the latter's activities in the country.

\section{The OSCE in Kazakhstan's foreign and security policy}

The strengthening of international security cooperation within the context of the OSCE figures in Kazakhstan's political discourse as one of the main areas of its security policy. ${ }^{3}$ Kazakhstan also associates the development of green economy, energy security, disaster prevention, and the promotion of sustainable connectivity with the OSCE. ${ }^{4}$ A number of policy documents adopted by Kazakhstan refer to the OSCE. The Comprehensive Plan for the Implementation of State Policy in the Religious Sphere for 20212023 , for example, states that "the country's legislation complies with the basic principles underpinning the international standards adopted by the OSCE." 5 Kazakhstan extends the mandate of the OSCE Programme Office in Nur-Sultan on an annual basis, emphasizing the im- portance of its work in all three OSCE security dimensions. ${ }^{6}$

At the same time, however, Kazakhstan regards the OSCE as just one among several European and Eurasian organizations. The official discourse often refers not to Kazakhstan's participation "in" the OSCE but to cooperation "with" the OSCE. The Concept of Foreign Policy of the Republic of Kazakhstan for 2020-2030 mentions the OSCE only once when identifying its priorities for regional and multilateral diplomacy, alongside the Collective Security Treaty Organization, the Council of Europe, and NATO. ${ }^{7}$ The OSCE is thus seen as "external" to Kazakhstan; the state seems not to accept the Organization's principles and values as its own but rather views them as imposed from the outside.

There is no systematic discussion in Kazakhstan at the governmental or parliamentary level of the significance of the OSCE for the country or of ways to make better use of it. Attention to the OSCE is ad hoc and determined primarily by the activities of the Organization itself, for example the monitoring of the parliamentary elections in January 2021, assessed as lacking competition and having systemic limitations, and the visit to Kazakhstan by Chairperson-in-Office Ann Linde in April 2021.

Kazakhstan tends to use the OSCE as part of its branding diplomacy, aimed at "placing Nur-Sultan in a visible position". ${ }^{8}$ It still attributes great importance to its 2010 Chairpersonship, emphasizing that it was "the first among the CIS [Commonwealth of Independent States] member states and the first among the 
countries of Asia, the Muslim and Turkicspeaking world" to chair the Organization. ${ }^{9}$ It views the appointment of Kazakh diplomat Kairat Abdrakhmanov to the position of High Commissioner on National Minorities in 2020 in a similar vein. ${ }^{10}$

\section{Expectations of the OSCE}

Aside from the general expectation that the OSCE should revive the "spirit of Helsinki" and enhance the effectiveness of its work, Kazakhstan does not usually formulate any specific expectations or proposals regarding the Organization. However, an analysis of official documents and speeches reveals a number of separate but interrelated areas of special interest.

First, from a regional security perspective, Kazakhstan maintains that it is important for the OSCE to increase its efforts to resolve the protracted conflicts in the OSCE area and to promote stability in Afghanistan. The government believes that Kazakhstan can contribute to these efforts by building on its experience as an intermediary, with respect to the violence in neighbouring Kyrgyzstan during its Chairpersonship in 2010 and as host of the Astana process, to resolve the situation in Syria.

Second, Kazakhstan is of the opinion that the OSCE's activities in the economic and environmental dimension "can be a catalyst for reducing tensions and strengthening confidence-building measures among the OSCE participating States". ${ }^{11}$ In particular, it expects that the
OSCE can support the development of transport corridors connecting Asia and Europe. ${ }^{12}$

Third, Kazakhstan supports regional and subregional projects in Central Asia, ${ }^{13}$ including efforts to synergize the work of the OSCE field operations in Central Asia in areas such as counterterrorism, anti-corruption, border and water resource management, and the development of digitalization, green economy, good governance, and environmental protection. It supports the activities of the OSCE Academy in Bishkek and the OSCE Border Management Staff College in Dushanbe. ${ }^{14}$

Fourth, Kazakhstan seeks to use the OSCE platform to raise its international visibility. It has proposed intensifying the OSCE's interaction with the Conference on Interaction and Confidence Building Measures in Asia as part of its foreign policy initiative "Three Dialogues". ${ }^{15}$ Kazakhstan's campaign to establish an OSCE thematic centre or regional hub for sustainable connectivity in its capital, first announced in 2017 and much disputed among participating States, can also be seen as an effort to enhance its international reputation. ${ }^{16}$ Kazakhstan believes it is important for OSCE structures to be spread evenly across the geographic area of its participating States as a way of increasing mutual trust and understanding. ${ }^{17}$

Some of these proposals are more specific and feasible than others. While the idea of developing transport corridors connecting Asia and Europe and the proposal to intensify the OSCE's regional and subregional activities are of a practical nature and can be implemented, 
the proposal to intensify its work on conflict resolution and promote global dialogue initiatives is less realistic and largely declarative. Kazakhstan's claim regarding the significance and success of its experience in conflict mediation is also exaggerated.

Certain political figures in Kazakhstan have also voiced proposals for the OSCE's work. For example, former OSCE Chairperson-in-Office Kanat Saudabayev has identified consolidating efforts in the fight against COVID-19, countering cyberattacks, and convening a new OSCE Summit as topical areas of engagement. ${ }^{18}$ These ideas, although in line with Kazakhstan's general rhetoric, are not official, however.

\section{Perception of problems faced by the OSCE}

As of 2021, Kazakhstan does not engage in direct official and systematic criticism of the OSCE, apart from general remarks with respect to the weakening of the "spirit of Helsinki" and the "spirit of Astana", the loss of mutual trust and space for dialogue, and the escalation of tensions. ${ }^{19}$ When Kazakhstan does voice criticism of the OSCE, it is usually in response to negative comments from individual OSCE structures, primarily regarding the observance of human rights, fundamental freedoms, and democratic procedures in the country.

In 2010, President Nazarbayev published an article on key problems faced by the OSCE. ${ }^{20}$ In his view, these included the unequal involvement of participat- ing States in solving problems that are equally important to all; the disruption of the politico-military balance in the OSCE area; the existence of "frozen conflicts"; the fragmentation of the OSCE area into three zones (North America, Europe, and Asia) and the lack of integration of the Eurasian space into the Organization's capacity development process; the re-emergence of inter-ethnic and interreligious tensions; and the problem of illegal and irregular migration and the integration of migrants into host country societies. There is no reason to believe that Kazakhstan has changed its assessment of these issues since then. Individual references to these problems continue to be made in speeches and statements by Kazakh officials. At the same time, Kazakhstan continues to adhere to the idea that "the OSCE's core activities are based on well-established principles, standards and rules, which it does not intend to abandon, as they embody the spirit of the Organization." 21

\section{The OSCE as seen by civil society and academia}

There is no broad, systematic discussion of OSCE issues in Kazakhstan's civil society or academic community. Expert assessments of the OSCE can usually be found only in specialized studies, such as the OSCE Network study "Central Asian Narratives on the OSCE". 22 Opinions on the OSCE vary widely, and there is no clearly definable common view.

Most experts close to government circles agree that the OSCE's work is im- 
portant but that its projects should be oriented more towards activities such as support for law enforcement agencies or border control. Representatives of the independent academic community and civil society believe that the OSCE does little to address human rights and that the majority of its projects in this field are declarative in nature, lacking real substance.

Academics tend to criticize the OSCE's projects in Kazakhstan for their limited scope and ineffective implementation, due to excessive formalization. They note that the topics, agendas, and participants of projects and events are subject to a multi-stage coordination process between and within the official structures of Kazakhstan and the Organization, which leads to a loss of critical content and relevance. They complain that OSCE activities are mostly reactive in nature, responding to requests coming from state bodies, and unlikely to make a real difference to the quality of the public service. They point out that there is no record of how OSCEorganized overseas visits and study tours, roundtable discussions, and training sessions for civil servants affect the quality of ministries' work, and they question the substance and relevance of their recommendations.

Another problem, according to experts and activists, is that it is difficult to identify the actual beneficiaries of OSCE activities. For example, the meeting of Chairperson-in-Office Linde with representatives of Kazakhstan's civil society was criticized for its closed nature and non-transparent procedure for selecting participants. ${ }^{23}$ Experts and activists often perceive both foreign experts invited by the OSCE and programme staff as incompetent and uninformed about the situation in Kazakhstan, and this has a negative impact on the OSCE's image.

Alongside this criticism, representatives of civil society and academia also note positive aspects of the OSCE's operation, both in Kazakhstan and as a whole. They highlight its effectiveness in facilitating participating States' cooperation in the politico-military and economic and environmental dimensions of security. They also positively note that the OSCE provides a platform for independent civil society organizations to voice their positions, first and foremost on human dimension issues, for example at the annual Human Dimension Implementation Meeting in Warsaw.

\section{Looking to the future}

Kazakhstan will likely maintain its approach to and level of participation in the OSCE in the medium term. It will continue to declare its commitment to the Organization's goals and values and rhetorically identify the OSCE as one of its foreign policy priorities. In doing so, however, it will regard the OSCE not as a key institution but as one among several European and Eurasian organizations.

Kazakhstan will continue to use the OSCE as a platform for raising its international profile as part of its branding diplomacy, including by lobbying for the establishment of an OSCE thematic centre in Kazakhstan and promoting its diplomats to key positions within the Or- 
ganization. It will continue to encourage regional and subregional OSCE projects, especially in the economic and environmental dimension, including on promoting transport corridors connecting Asia and Europe. Finally, Kazakhstan will continue to attach importance to mediation and conflict resolution, particularly with a view to Central Asia and the situation in Afghanistan.

\section{Notes}

1 Robert Cooper, "Russia, the West and Global Civilization”, in: Sergei Medvedev/Alexander Konovalov/Sergei Oznobishchev (eds.), Russia and the West at the Millennium: Global Imperatives and Domestic Policies, GarmischPartenkirchen: George C. Marshall European Center for Security Studies, 2003, p. 22.

2 See: President of the Republic of Kazakhstan, Decree No. 653 of 29 August 2008 on the State Programme "Path to Europe", "Adilet" Legal Information System of Regulatory Legal Acts of the Republic of Kazakhstan, http://adilet.zan.kz /rus/docs/U080000653 [in Russian].

3 President of the Republic of Kazakhstan, Decree No. 554 of 29 September 2017 on Approval of the Military Doctrine of the Republic of Kazakhstan, "Adilet" Legal Information System of Regulatory Legal Acts of the Republic of Kazakhstan, https://adilet.zan.kz/eng/docs/U17000005 54

4 "Statement of Minister of Foreign Affairs of the Republic of Kazakhstan B. Atamkulov at the Informal OSCE Ministerial Gathering, Ministry of Foreign Affairs of the Republic of Kazakhstan”, Embassy of the Republic of Kazakhstan in Ukraine, 10 July 2019, https://www.gov.k z/memleket/entities/mfa-kiev/press/news/ details/49963?lang=en

Government of the Republic of Kazakhstan, Decision No. 953 of 31 December 2020 on the approval of the Comprehensive Plan for the Implementation of State Policy in the Religious Sphere for 2021-2023, "Adilet" Legal Information System of Regulatory Legal Acts of the Republic of Kazakhstan, http://adilet.zan. kz/rus/docs/P2000000953 [in Kazakh and Russian].

6 OSCE, Permanent Council Decision No. 1364 on the Extension of the Mandate of the OSCE Programme Office in Nur-Sultan, Interpretative Statement, PC.DEC/ 1364, 19 December 2019, https://www.os ce.org/permanent-council/442954

President of the Republic of Kazakhstan, Decree No. 280 of 6 March 2020 on the Concept of Foreign Policy of the Republic of Kazakhstan for 2020-2030, "Adilet" Legal Information System of Regulatory Legal Acts of the Republic of Kazakhstan, https://adilet.zan.kz/eng/doc s/U2000000280

8 Ana-Maria Anghelescu, "Does it matter that the new OSCE High Commissioner for National Minorities is from Kazakhstan?", The Diplomat, 16 December 2020, https://thediplomat.com/2020/12 /does-it-matter-that-the-new-osce-high-co mmissioner-for-national-minorities-is-fro m-kazakhstan/

"OSCE Summit 2010: Kazakhstan as a regional and global leader", The Library of the First President of the Republic of Kazakhstan - Elbassy, 7 December 2020, https://presidentlibrary.kz/en/news/osce-s ummit-2010-kazakhstan-regional-and-glo bal-leader. See also: "International online conference 'OSCE Astana Summit 2010: Historical Significance and Relevance", Ministry of Foreign Affairs of the Republic of Kazakhstan, 19 February 2021, https://www.gov.kz/memleket/entities/m $\mathrm{fa} /$ press/news/details/163332?lang=en 
"Kazakh diplomat appointed OSCE High Commissioner on National Minorities", Ministry of Foreign Affairs of the Republic of Kazakhstan, 4 December 2020, https://www.gov.kz/memleket/entities/m $\mathrm{fa} /$ press/news/details/131951?lang=en

“Kazakhstan's foreign policy initiatives presented at OSCE Ministerial Council meeting", Embassy of the Republic of Kazakhstan in Ukraine, 6 December 2019, https://www.gov.kz/memleket/en tities/mfa-kiev/press/news/details/51524? ang=en

“Председатель ОБСЕ прибыла в Казахстан” [OSCE Chairperson arrives in Kazakhstan], Хабар 24. 12 апреля 2021, https://24.kz/ru/news/policy/item /467167-predsedatel-obse-pribyla-v-kazak hstan [in Russian].

13 OSCE, cited above (Note 6).

14 "Kazakhstan strengthens cooperation with Central Asian countries within the OSCE”, Embassy of the Republic of Kazakhstan to the Republic of Austria, Permanent Mission to the International Organizations in Vienna, 21 May 2020, https:/www.gov.kz/memleket/entities/m fa-vienna/press/news/details/kazahstan-uk replyaet-sotrudnichestvo-so-stranami-cent ralnoy-azii-v-ramkah-obse?lang=en

"Nursultan Nazarbayev predlozhil novuyu geopoliticheskuyu realnost' 'Tri D'" [Nursultan Nazarbayev proposes new geopolitical reality "Three Ds"], "Akorda" Official Website of the President of the Republic of Kazakhstan, 27 April 2019, https:/www.akorda.kz/ru/events/ international_community/foreign_visi ts/nursultan-nazarbaev-predlozhil-novu yu-geopoliticheskuyu-realnost-tri-d [in Russian].

“Kazakhstan's foreign policy initiatives presented at OSCE Ministerial Council meeting”, Embassy of the Republic of Kazakhstan in Ukraine, 6 December 2019, https://www.gov.kz/memleket/en tities/mfa-kiev/press/news/details/51524? ang=en. See also: Sebastian Mayer, "Kazakhstan's OSCE Connectivity Ambitions: Trade Promotion and Norm Resistance", IFSH (ed.), OSCE Insights 2020, BadenBaden: Nomos, 2020, https://doi.org/10.5 771/9783748922339-04

17 "Kairat Abdrakhmanov vstretilsya s General'nym sekretarem OBSE" [Kairat Abdrakhmanov meets OSCE Secretary General], Baige News, 11 October 2018, https://baigenews.kz/news/kairat_abdr ahmanov_vstretilsya_s_generalnim_sekre tarem_obse/ [in Russian].

18 Kulpash Konyrova, "Kazakhstan vyshel $s$ initsiativoy o neobkhodimosti sozyva novogo sammita OBSE" [Kazakhstan puts forward an initiative regarding the need to convene a new OSCE summit], Inbusiness.kz News Agency, 19 February 2021, https://inbusiness.kz/ru/news/ka zahstan-vyshel-s-iniciativoj-o-neobhodi mosti-sozyva-novogo-sammita-obse [in Russian].

19 Statement of Minister of Foreign Affairs of the Republic of Kazakhstan B. Atamkulov, cited above (Note 4).

20 Нурсултан Назарбаев, “Судьба и перспективы ОБСЕ” [Future and prospects of the OSCE], Известия, 28 января 2010, https://iz.ru/news/357755 [in Russian].

21 Ibid.

22 Irina Chernykh/Rustam Burnashev/Svetlana Dzardanova/Cornelius Friesendorf/ Rustam Makhmudov/Parviz Mullojanov, "Central Asian narratives on the OSCE", Research Report of the OSCE Network of Think Tanks and Academic Institutions, 2019.

23 'Predsedatel' OBSE vstretilas' v Nur-Sultane $s$ predstavitelyami grazhdanskogo obshchestva" [OSCE Chairperson-in-Office meets with civil society representatives in Nur-Sultan], Radio Azattyk, 13 April 2021, https://rus.azattyq.org/a/3120 1040.html [in Russian]. 


\title{
Sweden and the OSCE
}

\author{
Lars-Erik Lundin"
}

\section{Abstract}

Assuming the Chairpersonship of the OSCE in 2021, Sweden proposed that the Organization go back to basics, with a focus on upholding respect for OSCE commitments and the key principles established in the Helsinki Final Act of 1975. Non-compliance with these principles is perceived by Sweden as a threat to European security in general and to Sweden's security in particular. The Chairpersonship has therefore focused on three priorities: safeguarding the European security order; protecting the OSCE's comprehensive concept of security, in particular with reference to the human dimension; and promoting conflict resolution through small steps, supported by the direct and active engagement of the Chairperson-in-Office herself. The Swedish government has put particular emphasis on feminist foreign policy, setting gender equality and the enhancement of the role of women in the OSCE's work for peace and security as a fundamental goal.

\section{Back to basics}

One of Sweden's main incentives for applying for the 2021 OSCE Chairpersonship was supporting multilateralism, which has been an important part of Swedish foreign policy since the end of the Second World War. ${ }^{1}$ The Swedish Foreign Minister Ann Linde declared that the guiding principle of Sweden's Chairpersonship would be to "go back to basics", referring to the need to re-establish respect for the fundamental principles of the Organization and to secure its capacity to function. ${ }^{2}$

* Lars-Erik Lundin

Stockholm International Peace Research Institute (SIPRI)

larserik.lundin@gmail.com
Sweden has some forty years' experience in promoting a well-functioning OSCE. It hosted the three-year Stockholm Conference from 1984 to 1986, pioneering arms control and confidenceand security-building measures. In 1993, it was one of the first countries to chair the OSCE. Rolf Ekéus played a leading role in the Organization as OSCE High Commissioner on National Minorities between 2001 and 2004. Sweden has continuously engaged in collective efforts to consolidate the OSCE as an international organization, despite its lack of universally recognized international legal personality. In 2020, the Swedish delegation in Vienna worked alongside the Albanian Chair to contribute to the OSCE's daily operations and decision-making as it prepared to assume the Chairpersonship the 
following year. With the COVID-19 pandemic and the OSCE leadership crisis in the summer, 2020 was a challenging year for the Organization.

Sweden's declared intention to go back to basics referred above all to re-establishing respect for the fundamental principles enshrined in the 1975 Helsinki Final Act and the 1990 Charter of Paris. The commitments made in these historic consensus agreements underpin democracy, human rights, and the rule of law in the entire region, from Vancouver to Vladivostok. The participating States reaffirmed them as late as the OSCE Summit in Astana in 2010, ${ }^{3}$ but their implementation continues to backslide, in the East as well as the West. This backsliding also pertains to the principles of sovereignty and territorial integrity and is perceived by Sweden as a threat to the European security order in general and to Sweden's security in particular. Ensuring adherence to fundamental principles is therefore a crucial point in Sweden's security policy and its expectations with regard to the OSCE.

\section{Focus on hard security}

From a wider Swedish security policy perspective, the security situation in the OSCE area has become more challenging in recent years. In the late 1990s, Sweden still believed that participating States' views regarding democracy, human rights, and the rule of law were converging. There were fluctuations here and there, but overall the situation seemed to be gradually improving. Regional con- flicts seemed concentrated in what Sweden perceived as the periphery of the OSCE area, in South-Eastern and Eastern Europe, the Caucasus, and Central Asia. However, a few years into the new millennium, Russia's opposition to the socalled colour revolutions in Ukraine and Georgia signalled that the promising situation at the end of the Cold War was slowly deteriorating. Sweden perceives the annexation of Crimea (part of the territory of a participating State) by military means as a strong warning sign of the decline of security in the OSCE area.

For Sweden, divergence from key OSCE principles in recent years has serious military implications. It is concerned about the risks of threatening military escalation, not least given the enormous nuclear arsenals stationed in the European part of Russia. The tension in Belarus in 2021 has brought issues of conflict prevention and conflict resolution closer to the Swedish borders. The rapid technological development of weapons and other instruments of power, including in cyberspace, has also brought the protracted conflicts in the OSCE area closer to Sweden. The humanitarian suffering resulting from the recurring military conflict concerning Nagorno-Karabakh illustrates the destructive potential of these conflicts.

Against this background, Sweden is re-establishing its degraded national territorial defence and strengthening bilateral and multilateral cooperation. ${ }^{4}$ It has been a member of NATO's Partnership for Peace since 1994. As an EU member state, it has legal solidarity commitments, complemented by a unilateral solidarity 
declaration with the Nordic states, which also includes the non-EU members Iceland and Norway. Finally, Sweden has a statement of intent with the United States in the framework of its bilateral, and particularly close, defence cooperation with Finland.

At the same time, Sweden believes that deterrence must be complemented with confidence-building efforts. In Swedish official policy, hard security negotiations, including at the nuclear level, cannot be pursued without the participation of the most important powers on a basis of formal equality. This is where the OSCE, as a forum where the West and the East can pursue dialogue and cooperation, comes into the picture.

Sweden supports strengthening the OSCE as an arena for cooperation through efforts such as the OSCE Structured Dialogue on ongoing and future challenges and risks to security. The Structured Dialogue provides an opportunity for direct expert communication among government representatives from the fifty-seven capitals. Following up on its earlier position as Chair of the OSCE Forum for Security Cooperation in 2018, ${ }^{5}$ Sweden promotes efforts to strengthen arms control and to keep the Vienna Document and the Open Skies Treaty viable and functioning. ${ }^{6}$ Initiating a substantial dialogue on these issues is difficult, however, as Russia and other major powers resist the multilateralization of negotiations that affect their power assets, particularly those relating to nuclear capabilities. Nonetheless, as Russia has begun to seriously challenge the trend towards enlarging the EU and NATO, the need to re-establish overarching dialogue has become more pressing.

As OSCE Chair, Sweden regards efforts to resolve the protracted conflicts in the OSCE area as a priority. Maintaining a ceasefire in Ukraine remains an important objective, as does seeking progress in the Transnistrian conflict in Moldova. Sweden has long been aware of the danger of the spillover of conflict from countries outside the OSCE area, including Afghanistan. The Chairpersonin-Office has addressed this concern in her communication with counterparts in Central Asia.

\section{Championing the human dimension}

The human dimension was identified early on as an important part of the OSCE's comprehensive concept of security and plays a central role for Sweden. It comprises issues of human rights, democracy, and the rule of law but also relates to economic-environmental principles of the OSCE's second dimension and indeed to national minority rights and human security, traditionally seen as part of the OSCE's first, security-related dimension. Sweden's commitment to the human dimension-related norms that were solidified in the 1990 Paris Charter and subsequent OSCE documents agreed in the years following the Cold War constituted a necessary condition for the country's successful integration into the international community, as these were translated into legally binding commitments in several international cooperative con- 
texts, including the EU and the Council of Europe.

The human dimension is an area of friction among participating States, and therefore Swedish policy in this area is determined both by concern and by ambition. OSCE discussions on human dimension commitments no longer relate to the eastern part of the OSCE region alone. There has been backsliding in adherence to OSCE commitments in the western part as well, as demonstrated by the emergence of populism and xenophobia, especially after the migration crisis of 2015. This is a delicate issue for Sweden, both in the context of its upcoming presidency of the Council of the European Union in 2023 and in its cooperation with the OSCE Chair for 2022, Poland.

The Swedish government perceives the OSCE's ambitions for action on at least one of its commitments as too low: the promotion of the role of women in the prevention and resolution of conflicts and in peacebuilding. Although the implementation of the global Women, Peace and Security agenda initiated by UN Security Council Resolution 1325 has seen only limited progress over the past two decades, Sweden believes that this is an avenue for cooperation among OSCE participating States that offers hope even in the current political climate. An example of this is the dedication of the Economic and Environmental Forum to the topic of women's economic empowerment.

\section{A policy of small steps}

Sweden assumed the OSCE Chair in a climate of uncertainty about how domestic political changes in key countries (e.g. Joe Biden's election as US President) will affect multilateralism and the OSCE. Against this background, the Swedish Chair's approach has been to take small steps, underpinned by frequent engagement at the ministerial level.

The Chairperson-in-Office, Swedish Foreign Minister Ann Linde, has made a number of public appearances, including before the UN Security Council, ${ }^{7}$ and has travelled frequently to conflict areas. She met bilaterally with the Russian Foreign Minister ${ }^{8}$ and appeared before the US Helsinki Commission in an extensive hearing. ${ }^{9}$ Together with her Special Representatives, she conducted a series of visits to the field early on in 2021. ${ }^{10}$

The Swedish Chair has considered it important to work with OSCE institutions and field operations to identify areas of potential cooperation and progress in the current political climate and to avoid duplication with the work of other international organizations. A major focus has been going local and upgrading the importance of community security. An example of this is the support provided by the OSCE Programme Office in Bishkek to women leaders seeking to defuse inter-ethnic violence in Osh and other locations in southern Kyrgyzstan. In regions where conflict remains latent, such as Central Asia, Sweden has sought to contribute to efforts in conflict resolution. 


\section{Conclusion and recommendations}

Seeking to circumvent political obstacles by taking small steps is characteristic of the Swedish approach to security. Based on the lessons it has learned during its Chairpersonship, a number of recommendations can be formulated that could help the OSCE to move forward. ${ }^{11}$ Sweden has found it advantageous to seek agreement on procedure before substance and to address problems in their local context instead of seeking global solutions. It has proved beneficial to focus on less contentious areas of cooperation, notably in the second (economic and environmental) dimension, and on common threats and challenges, notably transnational threats. Sweden has found it important to establish dialogue between capitals (rather than exclusively in Vienna) and to seek informal channels of communication. Finally, Sweden's experience as OSCE Chair during the COVID-19 pandemic has required creativity in finding ways to carry on despite the crisis, especially through innovations in the field of digital communication. These innovations could be further developed to transform the OSCE into a hub for dialogue between participating States and civil society.

\section{Notes}

1 Interviews and discussions with representatives of the Chair have been conducted off the record. A series of eleven podcasts produced by the author with official representatives of the Chair and key experts is available as a SoundCloud playlist: https://soundcloud.com/lars-erik-lundi n/sets/podcasts-om-osse. See also: Folk och Försvar [Society and Defence], "The OSCE and the future of European security", YouTube, 6 May 2021, https://www.y outube.com/watch?v=9zNlUa_OpKY\&gt $\mathrm{k}$

See Helsinki Commission, "Hearing: Sweden's leadership of the OSCE", YouTube, 11 June 2021, https://www.yo utube.com/watch? $\mathrm{v}=\mathrm{iCsDyle6Xng \& amp}$ ;t=4s\&gt

"Astana declaration adopted at OSCE Summit charts way forward", OSCE, 2 December 2010, https://www.osce.org/ci o/74236

"Objectives for Swedish total defence 2021-2025 - Government bill 'Totalförsvaret 2021-2025"', Government Offices of Sweden, 18 December 2020, https:/www.government.se/governme nt-policy/defence/objectives-for-swedish-t otal-defence-2021-2025---government-bill -totalforsvaret-20212025/

5 Jan Salestrand, Address by Mr. Jan Salestrand, State Secretary to the Minister for Defence, Sweden, at the opening session of the Forum for Security Co-operation, FSC.DEL/145/18, 5 September 2018, https://www.osce.org/files/f/docu ments/b/8/393464.pdf

"Johan Huovinen on confidence- and security-building measures in the OSCE", SoundCloud, December 2020, https://sou ndcloud.com/lars-erik-lundin/forutsattni ngarna-for-fortroende-och-sakerhetsskapa nde-atgarder-i-osse. Note also statements to this effect by Ann Linde before the US Helsinki Commission from minute 32: "Appearance at Helsinki Commission by Ann Linde", YouTube, 11 June 2021, https://www.youtube.com/watch?v=iCsD yle6Xng\&t $=4 \mathrm{~s}$

$7 \quad$ "Briefing by H.E. Ms. Ann Linde, Minister for Foreign Affairs of Sweden and OSCE Chairperson-in-Office to the United Nations Security Council”, Govern- 
ment Offices of Sweden, 10 March 2021, https://www.government.se/speeches/202 1/03/briefing-by-h.e.-ms.-ann-linde-minist er-for-foreign-affairs-of-sweden-and-osce-c hairperson-in-office-to-the-united-nations -security-council/

8 "OSCE Chairperson-in-Office Ann Linde discusses OSCE agenda with Russian Foreign Minister Lavrov in Moscow", OSCE, 3 February 2021, https://www.o sce.org/chairmanship/477439

9 For Ann Linde's appearance at the Helsinki Commission, summarizing
Chair activities and priorities after five months, see: Helsinki Commission, cited above (Note 2).

10 See, for example, "OSCE Chairperson-inOffice Linde concludes official visit to Ukraine”, OSCE, 16 June 2021, https:// www.osce.org/chairmanship/489845\&gt

11 This is a collection of suggestions based on the author's analysis, commented upon in positive terms by representatives of the Chair. However, it is not a formal list of deliverables for the Ministerial Council. 


\title{
Poland and the OSCE
}

\author{
Eukasz Kulesa"
}

Abstract

Increasingly feeling threatened by security developments beyond its eastern border and seeking tangible security guarantees, Poland has tended to view the OSCE as having limited value. Its successful bid for the 2022 OSCE Chairpersonship has temporarily shifted Warsaw's perception of the importance of the OSCE, however, which has otherwise been dwarfed by NATO and the EU in Polish foreign and security policy. Although there has been limited public, expert, and academic interest in the OSCE, Poland appreciates the unique features of the Organization and aims to remain active within the framework of its comprehensive approach to security, with an emphasis on increasing the effectiveness of the politico-military dimension and its role in conflict areas, particularly in Eastern Europe. At the same time, due to the highly adversarial nature of relations among participating States and weaknesses affecting the functioning of the OSCE, Poland does not have high hopes for the OSCE's ability to address crucial security challenges in Europe.

\section{Introduction}

The OSCE's importance to Poland has been temporarily elevated as a result of its successful bid for the 2022 Chairpersonship. As the upcoming OSCE Chair, Poland has increased its involvement in the OSCE, serving as a member of the OSCE Troika and as Chair of the OSCE Mediterranean Partnership for Co-operation Contact Group since January 2021. It is likely that 2022 will be the year of the OSCE for Polish diplomacy. As Minister of Foreign Affairs Zbigniew Rau put it in July 2021, Poland "will spare no effort in assisting participating States in fostering dialogue while guarding the OSCE's principles and commitments". ${ }^{1}$

* Łukasz Kulesa

Polish Institute of International Affairs kulesa@pism.pl
Nevertheless, the increased attention given to the OSCE does not necessarily signal a major shift in Poland's perception of the value of the Organization or its willingness to spearhead ground-breaking OSCE initiatives.

\section{The OSCE in Polish foreign and security policy}

Increasingly feeling threatened by security developments beyond its eastern border and seeking tangible security guarantees, Poland has tended to view the OSCE as having limited value. Even before Russia's occupation of Crimea, the CSCE/OSCE's role in Polish foreign and security policy was dwarfed by the influence of NATO and the EU. ${ }^{2}$ Polish security policy is based on four mutually reinforcing pillars: membership in NATO 
and the EU, a security partnership with the United States, and regional security cooperation. Since the deterioration of Poland's relationship with Russia, the importance of structures and relationships that provide Poland with credible deterrence and influence options has increased significantly. In this context, the OSCE is of limited value compared with NATO (as a provider of hard security guarantees) and the EU (with its comprehensive Eastern Partnership and Eastern policy towards Russia and Central Asia).

The OSCE is commonly mentioned in Polish strategic documents, although its role has not been set out in detail. For example, the 2020 National Security Strategy stipulates only that Poland will "take steps to enhance the effectiveness [...] of the Organization for Security and Co-operation in Europe as [a] vital part of the cooperative security system in Europe". ${ }^{3}$ With the exception of the writings of former Foreign Minister and international security expert Professor Adam Daniel Rotfeld, there has been limited public, media, expert, and academic interest in the OSCE. ${ }^{4}$ The Polish delegation to the OSCE Parliamentary Assembly remains active, but neither the parliament nor its foreign affairs committees have held recent OSCE-specific debates.

Nonetheless, this does not make the OSCE irrelevant to Poland. Poland recognizes the distinctive position of the OSCE as a regional security organization based on a well-developed set of common principles and commitments, with an inclusive membership and important historical accomplishments. The Organization is one of the pillars of the rules-based international order which Poland is interested in upholding. Explaining the rationale for applying for the OSCE Chairpersonship, Foreign Minister Jacek Czaputowicz noted Poland's appreciation of the Organization's role in promoting stability in Europe and expressed its willingness to act as an "impartial intermediary" facilitating cooperation. ${ }^{5}$

Finally, there is a direct link between the OSCE's agenda and regional priorities in Polish foreign and security policy. This principally concerns Eastern Europe and the South Caucasus, the Western Balkans, and Central Asia. The Organization's first (politico-military) dimension of security is important to Poland's aim of increasing military transparency and predictability. Finally, the OSCE remains a forum where Poland can signal its position on important European security issues, including the application of additional pressure on the Belarusian regime and Russia.

\section{Perception of the OSCE's role and capabilities}

Poland views the OSCE area as facing a number of challenges, including ongoing conflicts, political crises and sub-regional flashpoints, a range of transnational threats, and problems brought on by the COVID pandemic. The OSCE itself, however, is not viewed as capable of playing a leading role in dealing with these challenges. Poland has thus taken a pragmatic, down-to-earth approach to the OSCE's role and agenda. It has been wary of calls to elevate the Organization to a cen- 
tral position in the European security system or to turn it into a structure for coordinating other regional organizations. From Poland's perspective, this would contravene the centrality of NATO and the EU in its foreign policy and would give Russia the chance to increase its influence. It also rejects the notion that some of the basic principles included in the Helsinki Final Act, the Paris Charter, and other OSCE documents are outdated and that the Organization should not hold countries accountable but simply accept the fact that a number of OSCE participating States are autocratic regimes.

Poland has limited expectations with regard to the OSCE's ability to resolve security crises in Europe. In the case of Russia's occupation of Crimea and its presence in the areas of Donetsk and Lugansk, but also in the context of the Russia-Georgia conflict, Nagorno-Karabakh, and Transnistria, the interests of the involved parties diverge greatly, and the Organization has neither the political power nor the instruments necessary to put sustainable pressure on them or to enforce a lasting solution. It can, however, utilize its conflict management toolbox to stabilize the situation in these areas, ameliorate humanitarian challenges, and facilitate dialogue. In this respect, for example, the impact of the OSCE Special Monitoring Mission (SMM) on the situation in eastern Ukraine is viewed positively (Poland contributed to the mission by seconding personnel and providing COVID vaccinations to SMM staff in June 2021), ${ }^{6}$ but a lasting solution to the crisis would - at least from Poland's perspective - primarily require a change of policy on Russia's part. The 2020 Nagorno-Karabakh war between Azerbaijan and Armenia also revealed the limits of the OSCE's utility in the high crisis phase of the conflict cycle.

It cannot be assumed that the OSCE will be able to shield itself from escalating tensions among its participating States. Poland itself has not shied away from criticizing participating States that, in its view, contravene OSCE principles and commitments. It is also supportive of close coordination between NATO and EU countries and of maintaining cohesion between the policy positions adopted by NATO and the EU and the activities of the members in Vienna. At the same time, it has raised concerns about the politicization of nearly every aspect of the functioning of the OSCE - including budget cycle decisions and what should be treated as routine extensions of field operation mandates.

The linking of unrelated or loosely related issues to gain leverage has also been seen as a problem by Poland. In some cases, this has resulted in a single participating State taking the entire Organization hostage over its particular demands, often narrowly defined. One example cited by former OSCE Secretary General Greminger was the blocking of budget process reform due to disagreement over the addition of a "no responsibility for content" disclaimer to documents distributed through the OSCE system. ${ }^{7}$ The 2020 crisis over the prolongation of the mandates of the heads of OSCE institutions and the Secretariat can be seen as a consequence of such an approach. What apparently started with one coun- 
try's reservations about the head of an OSCE institution spiralled into a larger crisis that resulted in a failure to renew the appointments of the Secretary General, the Representative on Freedom of the Media, the High Commissioner on National Minorities, and the Director of the Office for Democratic Institutions and Human Rights (ODIHR) in July 2020. ${ }^{8}$

In short, Poland views the OSCE as a valuable but not central element of the European security architecture and has tailored its expectations of and engagement with the Organization accordingly. Despite its weaknesses, the OSCE's normative framework and its comprehensive approach to security continue to be seen as positive factors. In addition, Poland appreciates the practical contributions of the Organization on the ground, especially in conflict areas.

\section{Poland's engagement}

Poland has a respectable record of engagement with the OSCE. It hosts both ODIHR and the annual Human Dimension Implementation Meeting - Europe's largest regular human rights gathering. Poland served as OSCE Chair in 1998, and Polish diplomats have held important positions within the Organization. Ambassador Adam Kobieracki led the Conflict Prevention Centre from 2011 to 2015, and Ambassador Andrzej Kasprzyk has acted as Personal Representative of the Chairperson-in-Office on the conflict dealt with by the OSCE Minsk Conference (Nagorno-Karabakh) since 1996.
The decision to apply for the OSCE Chairpersonship signals that Poland now views responsibility for European and Eurasian security as requiring a readiness to go beyond the remits of its NATO and EU membership. This is in line with Poland's broader international ambitions, as indicated by its non-permanent membership in the UN Security Council in 2018/2019. During its term, Poland focused on themes that also play into its OSCE Chairpersonship: the strengthening of international law, the protection of civilians in armed conflicts, and the security situation in Eastern Europe. Presenting the outline of the 2022 Polish Chairpersonship programme in July 2021, Foreign Affairs Minister Rau identified three cautiously formulated objectives, roughly corresponding to the three OSCE dimensions: 1) supporting the OSCE's conflict resolution activities; 2) responding to post-COVID challenges through effective multilateralism; and 3) fully utilizing the Organization's potential to implement shared commitments.

The politico-military dimension has been the most important area of engagement for Poland by far, especially since the overall deterioration of the security situation in Central Europe. Poland has been active in the Structured Dialogue and in the Forum for Security Co-operation, raising the problem of the mismatch between the provisions of the 2011 Vienna Document (VD) on confidenceand security-building measures and contemporary armed forces operations. The problem has become more urgent as a result of what Poland views as Russian attempts to selectively implement 
or circumvent important elements of the VD, such as its declaration that its military manoeuvres fall just below notification and observation thresholds and its conducting of large-scale snap exercises. Poland has also drawn attention to the increased danger of military incidents, calling for the review and modification of the document's risk reduction provisions, including procedures for dealing with hazardous incidents and unusual military activities. Poland has consistently supported the modernization of the VD. It formulated its own proposals in this regard, which were integrated into a unitary joint proposal put forward by a group of states in 2019.9 With such modernizations blocked by Russia, Poland has been supportive of voluntary transparency measures, including briefings on military exercises and activities.

Poland remains concerned about the dismantlement of the European arms control architecture, closely linked to the OSCE's comprehensive security concept, and has accused Russia of undermining the Treaty on Conventional Armed Forces in Europe and the IntermediateRange Nuclear Forces Treaty. While it was supportive of the continuation of the Open Skies Treaty, it (along with the United States) raised the issue of Russian restrictions on access to territory for observation flights, especially involving flights over the Kaliningrad region. Poland thus refrained from criticizing the United States for withdrawing from the Treaty in May 2020 but reacted with "disappointment" to Russia's announcement of the initiation of its own withdrawal procedure in January 2021.
Poland is fully supportive of the crisis management efforts and activities undertaken within OSCE dialogue formats and processes. At the practical level, in the context of its Chairpersonship, it has been identifying areas where OSCE involvement can make a difference to individuals and communities affected by conflict, especially the most vulnerable groups. ${ }^{10}$ In this respect, Poland aims to better coordinate its own international assistance programme with OSCE activities.

The economic and environmental dimension of OSCE activity receives less attention in Warsaw than the others. Poland's aspirations for the economic dimension of the OSCE are driven by the pragmatic aim of connecting OSCE activities with policies pursued in the framework of other organizations and formats, including the UN, the EU, and the Organisation for Economic Co-operation and Development. Thus, for example, Poland would expect the OSCE to build on the work of other organizations in supporting a sustainable post-pandemic recovery. Poland is also likely to continue to highlight the link between economic development and combating money laundering and to support OSCE efforts in this regard, highlighting its own record in tightening the fiscal system and reducing the "grey zone" economy.

In countering climate change, Poland is likely to draw attention to the results of the $24^{\text {th }}$ Conference of the Parties to the United Nations Framework Convention on Climate Change, which took place in Poland in 2018, and especially to the Katowice Rulebook. In this regard, Poland 
has stressed the importance of a "just transition", which aims to safeguard and promote the interests of countries with mixed energy sources and regions that have thus far relied on fossil fuels and carbon-intensive industries. Closely connected to this issue is the highlighting of Poland's transborder cooperation in the Carpathian region in countering environmental degradation and protecting biodiversity. In the OSCE context of economic and environmental issues, its main aim is to raise awareness of these issues.

Within the human dimension, Poland is particularly focused on drawing attention to the situation in Belarus. In September 2020, it was among the seventeen states that invoked the Moscow Mechanism to investigate human rights violations in the country and remains highly critical of the Belarusian regime, including its harassment of representatives of the Polish minority and journalists. ${ }^{11}$ Poland will most likely insist on keeping the situation in Belarus and its repercussions high on the OSCE agenda and will seek to utilize all available OSCE tools to influence the situation there and in other potential crisis spots. Its broader human rights agenda in the context of the Chairpersonship seems to be aimed at working on a range of cross-cutting issues relevant to all participating States. This includes human rights in the digital era, the impact of the pandemic on human rights, the economic empowerment of women, freedom of religion and belief, and protection and support for specific groups, such as those with disabilities, children, and youth. Poland is also committed to promoting the protection of human rights in conflict zones. Traditionally, the issue of free and fair elections and election monitoring has been high on the Polish OSCE agenda.

It should be noted that internal developments in Poland and the performance of its election system (e.g. during the 2020 presidential elections) ${ }^{12}$ have been subject to scrutiny and critical reflection within the OSCE framework. For example, in recent years, several cases involving Poland have been raised by the OSCE Representative on Freedom of the Media. ${ }^{13}$

Poland has sought to act as a good international citizen within the Organization by being active in all dimensions and all major areas of OSCE activity and by contributing to strategic debates on the future of the Organization. These contributions include involvement both at the governmental level (the Corfu Process and the Structured Dialogue) and at the expert level (the participation of Professor Adam Daniel Rotfeld in the Panel of Eminent Persons ${ }^{14}$ and engagement with the Cooperative Security Initiative). ${ }^{15}$

\section{Poland and future OSCE scenarios}

It would be an exaggeration to claim that the OSCE holds a prominent position in Polish foreign and security policy. The Organization's limitations are well understood in Poland, and there is little expectation that the European security crises can be overcome through actions or stand-alone initiatives pursued within the OSCE (such as a 2025 "anniversary" summit). 
As OSCE Chair, Poland does not expect to be a driver of major breakthroughs. Nevertheless, it seems to be genuinely interested in making modest gains in implementing its own priorities and the Organization's overall agen$\mathrm{da}$ and in impartially fulfilling its obligations as Chair, thus contributing to stabilizing the OSCE area and the efficient functioning of the Organization. Given the possibility that a sudden development could affect its activities, there may be more crisis management than implementation of the pre-planned agenda ahead for Poland in 2022.

Looking further ahead, Poland is likely to maintain its current attitude towards the Organization. The OSCE has value for Poland as a forum where dialogue and sectoral cooperation can be pursued even with adversaries - especially when other channels of communication remain closed or severely constrained. Although the OSCE's mechanisms may not succeed in resolving ongoing conflicts in Europe, the OSCE can provide an inclusive framework for facilitating and securing progress elsewhere.

In the unlikely scenario that the political interests of the United States, Russia, and the major European countries converge on the need to genuinely improve European security, Poland's perception of the role and importance of the OSCE would change immediately. Poland would probably actively participate in any OSCE-wide discussions on the restoration of a pan-European security system. It would primarily be looking for evidence of fundamental change in Russian security thinking, however, and would not support any solutions that gave Russia an outsized role or veto over developments in the common neighbourhood.

In the more negative scenario of an existential crisis within the OSCE - triggered, for example, by the threat of or actual withdrawal of any of its participating States ${ }^{16}$ or the obstruction of its activities - Poland would of course attempt (with other like-minded states) to defuse the situation. At the same time, Poland would be unlikely to accept the excessive demands of any state that sought to coerce the Organization to adapt to its preferences.

\section{Notes}

"Minister Zbigniew Rau takes part in OSCE Permanent Council meeting in Vienna”, MFA Press Office, 15 July 2021, https://www.gov.pl/web/diplomacy/mini ster-zbigniew-rau-takes-part-in-osce-perm anent-council-meeting-in-vienna

2 Marcin Bużański, "Poland - Flexibility to Address a Broad Area of Subjects", in: Alexandra Dienes/Reinhard Krumm (eds.), Perceptions of the OSCE in Europe and the USA, Vienna: FES Regional Office for Cooperation and Piece in Europe, 2018, 75-81, pp. 76-77.

"National Security Strategy of the Republic of Poland", 12 May 2020, p. 25, https:/ /www.bbn.gov.pl/ftp/dokumenty/Nation al_Security_Strategy_of_the_Republic_of _Poland_2020.pdf

4 E.g. Adam Daniel Rotfeld, "A Euro-Atlantic and Eurasian Security Community: A New Role for the OSCE", in: IFSH (ed.), OSCE Yearbook 2013, BadenBaden: Nomos, 2014, 53-66. 
5 "Poland to chair OSCE in 2022", MFA Press Office, 5 December 2019, https://w ww.gov.pl/web/osce/poland-to-chair-the -osce-in-2022

6 As of December 2020, thirty-six Polish nationals had been seconded to the SMM and one Polish national had been seconded to the OSCE observer mission at the Ukrainian-Russian border.

7 Thomas Greminger, "Making the OSCE More Effective: Practical Recommendations from a Former Secretary General", IFSH (ed.), OSCE Insights 2021, BadenBaden: Nomos, 2022, https://doi.org/10.5 771/9783748911456

8 For details, see Walter Kemp, "Executed structures: Leadership crisis in the OSCE", Security and Human Rights Monitor, 14 July 2020, https://www.shr monitor.org/executed-structures-leadersh ip-crisis-in-the-osce/

9 "Germany presents proposals to the OSCE on adjusting the Vienna Document”, Federal Foreign Office Press Release, 23 October 2019, https:/www.aus waertiges-amt.de/en/newsroom/news/ann en-vienna-document-osce/2259666

10 Interview with MFA official, May 2021.

11 "Joint statement invoking the Moscow Mechanism in relation to serious human rights violations in Belarus", Ministry of Foreign Affairs of the Republic of Lithuania, 5 November 2020, https://urm.lt/def ault/en/news/joint-statement-invoking-th e-moscow-mechanism-in-relation-to-serio us-human-rights-violations-in-belarus

12 OSCE, Republic of Poland, Presidential Elections 28 June and 12 July 2020, ODIHR Special Election Assessment Mission Final Report, 23 September 2020, https://www.osce.org/odihr/elections/pol and $/ 464601$

13 See: "Press statements of the OSCE Representative on Freedom of the Media on Poland", OSCE, https:/www.osce.org/fo $\mathrm{m} /$ statements/?filters=+im_taxonomy_vid _5:\%28274\%29\&solrsort=ds_date $\% 20$ des c\&rows $=10$

14 See "Panel of eminent persons", OSCE, https://www.osce.org/networks/pep

15 See the Cooperative Security Initiative website, https://www.cooperative-secur ity-initiative.org/

16 Andrey Kortunov, "To stay or not to stay? Seven concerns Russia has about the OSCE”, Russian International Affairs Council, 19 May 2021, https://russiancou ncil.ru/en/analytics-and-comments/analy tics/to-stay-or-not-to-stay-seven-concerns-r ussia-has-about-the-osce/ 


\title{
North Macedonia and the OSCE
}

\author{
Ana Krstinovska"
}

\section{Abstract}

This contribution discusses the prospects for North Macedonia's engagement with the OSCE by examining the country's expectations, the OSCE's standing in comparison with other international organizations, and the challenges and opportunities facing North Macedonia's 2023 OSCE Chairpersonship. It argues that, having largely contributed to the country's consolidation in the 1990s and 2000s, the OSCE has been relegated to a secondary role, behind the EU and NATO. Nevertheless, the OSCE's work, through the field operation in particular, is largely beneficial to North Macedonia's reform process, supporting its strategic objectives both to join the EU and to achieve the UN's Sustainable Development Goals. North Macedonia could use its 2023 Chairpersonship for self-affirmation, to increase the OSCE's visibility in the country, and to widely promote the role the Organization has played in North Macedonia's stabilization and transformation.

\section{Introduction}

The Republic of Macedonia became independent after the break-up of Yugoslavia in $1991 .^{1}$ It signed the Helsinki Final Act in July 1992 and, in September of the same year, welcomed the deployment of an OSCE field operation tasked with preventing the spill-over of the post-Yugoslav wars. The OSCE's efforts were enhanced by a UN Mission in 1993, enabling North Macedonia to avoid violent conflict at that time. Hence, the country "stands out as one of the relatively successful cases of the OSCE's conflict prevention efforts and a testing ground for

\footnotetext{
* Ana Krstinovska

ESTIMA

krstinovska@estima.mk
}

collaborative preventive actions on the part of the OSCE and the UN". 2

The circumstances were not so fortunate after 1999, however, when, following the war in Kosovo and the withdrawal of the United Nations Preventive Deployment Force, ethnic tensions in North Macedonia escalated, leading to internal armed conflict in 2001. While the OSCE was admittedly not the lead security actor in achieving peace, its Spillover Monitor Mission on the ground contributed to early warning, addressing subsequent refugee issues, and bringing the involved parties and the international community to the negotiation table. ${ }^{3}$ The peace brokered by the EU and the United States in August the same year was enshrined in the Ohrid Framework Agreement (OFA), which laid the foundations for a society 
that is respectful of diversity in terms of ethnicity, religion, culture, and language.

Over the past twenty years, the implementation of the OFA, and inter-ethnic confidence-building measures in particular, has been one of the country's key areas of engagement with the OSCE. Although inter-ethnic relations remain a topic of utmost concern to North Macedonia and the OFA power-sharing model is a recurrent source of political crises, ${ }^{4}$ the country has advanced in terms of reconciliation. It owes this progress in part to the work of both the OSCE's High Commissioner on National Minorities and the OSCE Spillover Monitor Mission to Skopje (later the OSCE Mission to Skopje). Following North Macedonia's consolidation, the OSCE has largely outlived its initial mandate of conflict prevention and resolution in the country. It is now perceived as a partner in the country's transition to a fully functioning democratic state.

The years following the deployment of an OSCE field operation to North Macedonia and its onsite cooperation with the UN, the EU, and NATO in the area of conflict management inspired abundant scholarship on the efficiency of the established mechanisms, their achievements, and their limitations. ${ }^{5}$ The evolution of the operation's mandate from conflict prevention to reconciliation and state-building has demonstrated the OSCE's ability to adjust to changing circumstances and the value of its long-term operations. ${ }^{6}$ While there is research related to the implementation of the OSCE Mission's evolving priorities and general engagement in North Macedonia in the 2000s, as well as the OSCE's role in specific policy areas, ${ }^{7}$ little is known about the success and sustainability of the OSCE-supported reforms. There has also been little explanation of the government's somewhat ambivalent attitudes towards the OSCE and its field presence in the country.

This paper examines the prospects for North Macedonia's engagement with the OSCE: What are North Macedonia's expectations of the OSCE? Where does the OSCE stand in comparison to other international organizations, and what are the potential areas for cooperation? What are the opportunities and challenges facing North Macedonia's OSCE Chairpersonship? The paper is based on official documents, media articles, reports, and semi-structured interviews with representatives of North Macedonia's institutions, civil society, and the OSCE Mission to Skopje. It also builds on the author's empirical observations during her work as a foreign policy advisor, diplomat, and official in North Macedonia's government (2013-2018).

\section{North Macedonia's interest in the OSCE}

North Macedonia's interest in the OSCE is pragmatic in nature. This is largely because the country is still in the process of elaborating its foreign policy and defining its priorities in bilateral relations and multilateral fora. ${ }^{8}$ Although the OSCE is still considered one of the most significant international organizations for North Macedonia (alongside the UN, the World Trade Organization, and the 
Council of Europe), it does not have the strategic importance of the EU and NATO. ${ }^{9}$ Moreover, following North Macedonia's accession to NATO in March 2020, there are signs that it would rather channel cooperation in security-related areas through NATO structures and its allies, scaling back cooperation with the OSCE. Hence, the focus of the government's engagement with the OSCE has been gradually shifting from the first (politico-military) to the second (economic-environmental) and third (human) dimensions, and the OSCE has been relegated to a secondary role compared to the EU and NATO. Nonetheless, North Macedonia sees the assumption of the OSCE Chairpersonship as a chance to enhance its international image and manifest its institutional capacities.

North Macedonia's reform agenda is determined by the EU accession process and the need to align domestic legislation and standards with the EU acquis. Given that both the EU and the OSCE are involved in similar areas, such as the judiciary, the media, good governance, migration, border management, and human rights, the OSCE's activities in the country largely contribute to its EU integration. All of these areas are part of the most important cluster of the EU's new enlargement policy. ${ }^{10}$ As North Macedonia prepares for negotiations to join the EU, it may well solicit the OSCE to provide further assistance to state institutions in these areas.

At the same time, national authorities sometimes raise the presence of the Mission to Skopje as a point of concern. OSCE field operations, all of which are located in South-Eastern and Eastern Europe, the South Caucasus, and Central Asia, are generally seen as "service providers in situations of crisis, transition and state building". ${ }^{11}$ The government views the fact that OSCE participating States gave the country responsibility for chairing the Organization in 2023 as recognition that it is no longer a security concern. The continued presence of a field operation could harm its image as a "success story".

That being said, the Mission to Skopje's longstanding experience and highly developed understanding of local needs and context have been instrumental to launching and conducting much-needed reform-related activities in North Macedonia, such as the introduction of multi-ethnic policing and court trial monitoring. In addition, the OSCE has shown flexibility in responding to the ad hoc needs of both state institutions and civil society, including by supporting the parliament's efforts to be more open and closer to the constituencies, assisting in the development of a legal framework for youth organization and participation in decision-making, and reaching out to vulnerable groups at the outbreak of the coronavirus pandemic. Discontinuing the work of the field operation would likely create significant gaps. Therefore, closing the Mission is not on the government's agenda for the moment. However, it may wish to direct discussions on its future mandate towards prioritizing its role in the country's reform process over its crisis prevention function. 
The OSCE as seen by civil society and the public

The OSCE has a good reputation among both the public administration and civil society. The OSCE's field presence is particularly significant for civil society, as it is largely dependent on external donor assistance for its activities and sees the Mission to Skopje as an important partner. Its visibility among the general public is more limited, however. This can partly be ascribed to its "quiet diplomacy"12 approach to managing sensitive situations and brokering between different stakeholders. Unlike the EU's approach, which consists of a blend of off-the-record meetings and public statements aimed at influencing public debate and providing direction for political and policy decisions, the OSCE usually works "behind the scenes", using its credibility and access to high-level decision-makers to provide advice and guidance. Hence, its actions and methods, as well as the efficiency of this approach, often remain outside the public eye.

The one area in which the work of the OSCE is clearly recognized by all stakeholders in the country, including the general public, is elections. North Macedonia invites the OSCE's Office for Democratic Institutions and Human Rights (ODIHR) to monitor all election cycles and types. The monitoring missions help to instil trust that the electoral cycle will be managed in line with international standards. Their reports and recommendations are usually accepted as a benchmark by both ruling and opposition parties across ethnic groups and are fed directly into an- nual progress reports for the European Commission. In 2021 North Macedonia engaged in a broad public debate on changes to the electoral model. It could benefit from ODIHR's assistance in shaping policy reform, promoting an inclusive model that reflects democratic standards, and addressing certain shortcomings of the power-sharing model established with the OFA.

Finally, environmental issues offer great potential for deeper cooperation between civil society and the OSCE. An OSCE-supported Aarhus Centre in Skopje was established in 2019, but its visibility and impact remain limited. ${ }^{13}$ Because North Macedonia is lagging behind in its commitments regarding the UN's Sustainable Development Goals (SDGs), ${ }^{14}$ and given the direct link between the OSCE's concept of comprehensive security and sustainable development, activities carried out by the Mission to Skopje in support of the achievement of the SDGs - SDG 16 on peace, justice, and strong institutions, but also SDG 4 on quality education, SDG 5 on gender equality, and SDG 10 on reducing inequalities - are a promising area of engagement. ${ }^{15}$

\section{The 2023 OSCE Chairpersonship}

North Macedonia's motivation to apply for the 2023 OSCE Chairpersonship was driven by a desire to boost its international image, manifest the institutional capacity expected of a NATO member and aspiring EU member, and contribute to the promotion of OSCE commitments. ${ }^{16}$ The government perceives the Chairper- 
sonship as an opportunity to present the country as a role model in areas such as handling inter-ethnic relations and resolving bilateral disputes (especially in the Balkans and Eastern Europe). However, there are a number of persisting problems in these areas that may compromise the appeal of the country's approach to other participating States. First, the OFA power-sharing model allows for ethnic issues to be (ab)used as a bargaining chip between political parties in their fight for power. Second, the Prespa agreement, signed with Greece in 2018, which obliged the Republic of Macedonia to change its constitutional name to North Macedonia, did not bring the country any closer to joining the EU, as the government had initially promised. Third, Bulgaria has vetoed North Macedonia's plans to open EU accession negotiations over issues related to the country's national identity, despite the fact that the two countries signed a treaty on good neighbourly relations in 2017.

The OSCE Chairpersonship will be North Macedonia's biggest challenge in multilateral diplomacy so far. State institutions will be required to mobilize significant resources and establish inclusive and efficient internal and external coordination mechanisms. The country will have to upscale its underdeveloped diplomatic network, especially in the South Caucasus and Central Asia, and fill ambassadorial positions in a number of important capitals, including Washington and Moscow. Moreover, despite recent bilateral tensions, it will need to find a way to engage with Russia if it wants to be perceived as an "honest broker".

\section{Conclusions and recommendations}

While the OSCE initially played an important role in conflict prevention and reconciliation, following North Macedonia's stabilization and consolidation process as a country its importance has been decreasing compared to the EU and NATO. The engagement of the OSCE, especially through its Mission to Skopje, contributes to North Macedonia's EU accession and reform agenda and to the achievement of the UN's SDGs. With that said, the synergetic potential of this engagement is not sufficiently exploited, the OSCE Mission to Skopje is sometimes stigmatized by state authorities, and elections are the only area where the OSCE's efforts are clearly recognized by the broader public. North Macedonia's 2023 OSCE Chairpersonship could help to increase the OSCE's visibility in the country, boost its international image, promote the OSCE's role in its democratic transformation, and build support for its EU integration.

As Chair, North Macedonia could highlight the country's specific interests in the OSCE and contribute to initiating a "Group of Friends of the OSCE" to discuss a new Helsinki 2025 agenda. It could use the annual procedure of extending the mandate of the OSCE Mission to Skopje as an opportunity to engage with other participating States in an evaluation of its achievements, organize a broad consultation process to prepare the Mission's mandate for the forthcoming period, and further enhance the OSCE's role in the country's reform process. 
North Macedonia's state institutions and the European Commission could benefit from the OSCE's monitoring role in areas other than elections (such as freedom of the media, the protection of national minorities, police reform, and human rights) to inform the country's annual progress reports. In particular, the OSCE's expertise and the work of the OSCE Mission to Skopje could be leveraged to make progress in EU accession chapter 10, which concerns media-related issues, as well as chapters 19 on social policy, 23 on fundamental rights and the judiciary, 24 on justice and domestic affairs, and 27 on the environment.

In terms of specific policy areas, North Macedonia's electoral reform should incorporate OSCE/ODIHR recommendations more explicitly. The Aarhus Centre Skopje should be given a more prominent role in policy development and monitoring. The OSCE Mission to Skopje should develop activities to assist in the achievement of the SDGs.

Given that the countries of the Western Balkans are becoming increasingly integrated and interdependent, North Macedonia's Chairpersonship could contribute not only to the country's self-affirmation but also to the positive perception within the OSCE of the entire region. As these countries' objectives related to the EU integration process coincide to a great extent with their OSCE commitments, a proactive and well-thoughtout approach during North Macedonia's Chairpersonship could build support for the process and counteract the "enlargement fatigue" of a number of EU member states. Hence, when formulating its priorities for the forthcoming Chairpersonship in 2023, North Macedonia's government should coordinate with other OSCE participating States in the Western Balkans and use the Chairpersonship to put forward common interests, foster positive public opinion towards the region among EU member states, and make headway on the stalled EU integration process.

Domestically, the government should consult and cooperate with civil society when formulating priorities for its OSCE Chairpersonship. As Chair, North Macedonia should conduct activities to increase the OSCE's visibility and importance in the country (such as a public campaign and events involving youth or grass-roots organizations) and promote the role of the OSCE in its democratic transformation.

\section{Notes}

I would like to express my gratitude to the interviewees for their insights and to Argyro Kartsonaki, Frank Evers, and the external reviewers for their comments on an earlier draft.

Alice Ackermann, "The Republic of Macedonia and the OSCE Preventive Diplomacy in Practice", in: IFSH (ed.), OSCE Yearbook 1997, Baden-Baden: Nomos, 1998, 69-75, p. 69.

3 "An end to the beginning of war: The OSCE's role in conflict prevention in Macedonia and Kosovo", Wilson Center, 9 February 2005, https://www.wilsoncent er.org/event/end-to-the-beginning-war-th e-osces-role-conflict-prevention-macedoni a-and-kosovo 
Nikola Ambarkov, "Features of the Macedonian Power-Sharing Model and its Future", in: Horizons International Scientific Journal 2016, 77-87, p. 81.

Emeric Rogier, "The Operational Role of the OSCE in the Field of Conflict Prevention: An Assessment of the Spillover Monitor Mission to Skopje (Macedonia)", in: Victor-Yves Ghebali/Daniel Warner (eds.), The Operational Role of the OSCE in South-Eastern Europe, London: Routledge, 2001, 46-51; Alice Ackermann, "The Prevention of Armed Conflicts as an Emerging Norm in International Conflict Management: The OSCE and the UN as Norm Leaders", in: Peace and Conflict Studies 1/2003, 1-16; Boyka Stefanova, "OSCE and Balkan Security", in: Journal of Balkan and Near Eastern Studies 1/2009, 43-60.

6 Victor-Yves Ghebali, "The OSCE LongTerm Missions: A Creative Tool under Challenge", in: Helsinki Monitor 3/2004, 202-208; Victor-Yves Ghebali, "The OSCE between crisis and reform: Towards a new lease on life", Geneva Centre for the Democratic Control of Armed Forces (DCAF) Policy Paper 10, November 2005, https://www.files.ethz.c h/isn/15051/PP10_Gh\%C3\%A9bali.pdf; Marc Perrin de Brichambaut, "The OSCE in South Eastern Europe”, in: Crossroads 1/2006, 104-112.

For example, on multi-ethnic policing: Ali Dikici, "Introducing Multi-Ethnic Policing in Macedonia: The Role of the OSCE”, in: Review of International Law and Politics 10/2007, 129-146; and on integrated education: Raffaele Mastrorocco, "OSCE and Civil Society in the Western Balkans: The Road to Reconciliation”, in: Anja Mihr (ed.), Transformation and Development, Cham: Springer, 2020, 83-100.

The work on the country's first ten-year strategy on foreign policy began in June 2021.
Zoran Zaev, Mandate letter to the Minister of Foreign Affairs Bujar Osmani, 3 September 2020, p. 3, https:/vlada.mk/sit es/default/files/img/mandatno_pismo_os mani.pdf

10 "Enhancing the accession process - A credible EU perspective for the Western Balkans”, European Commission, 2020, https://eur-lex.europa.eu/legal-content/E N/TXT/?uri=CELEX:52020DC0057

11 Wolfgang Zellner/Frank Evers et al., "The future of OSCE field operations (options)", OSCE Network of Think Tanks and Academic Institutions, December 2014, p. 3, https://osce-network .net/file-OSCE-Network/documents/The _Future_of_OSCE_Field_Operations_O ptions_.pdf

12 Walter Kemp (ed.), Quiet Diplomacy in Action: The OSCE High Commissioner on National Minorities, Martinus Nijhoff Publishers, 2001, https://www.osce.org/fi les/f/documents/6/7/78633.pdf

13 The Aarhus Centre Skopje is part of a network of more than sixty centres in more than a dozen European countries that campaign for the implementation of the 1998 United Nations Economic Commission for Europe Convention on Access to Information, Public Participation in Decision-making and Access to Justice in Environmental Matters (Aarhus Convention).

14 North Macedonia's SDG profile, https://d ashboards.sdgindex.org/profiles/mkd?fbc lid=IwAR3CYxZHyPrmO7ivQCbFNc-DJ e6C0EJdU6X0BNbLlJaieNUmRs0_fZWs ITU

15 OSCE website, https://www.osce.org/sust ainable-development-goals

16 Stephanie Liechtenstein, "North Macedonia and Estonia are seeking the OSCE Chairmanship", Security and Human Rights Monitor, 29 November 2020, https://www.shrmonitor.org/north-mac edonia-is-seeking-the-osce-chairmanship-i n-2023/ 


\section{Author information}

Rustam Burnashev is a professor at the Kazakh-German University in Almaty, Kazakhstan. He has taught at various higher education institutions in Uzbekistan and Kazakhstan. Previous positions include Director of Analytics and Consulting at the Institute of Political Solutions (Almaty, Kazakhstan, 2009-2013) and Head of the Foreign Policy Analysis Sector of the Institute for Strategic and Interregional Studies under the President of the Republic of Uzbekistan (1998-2000). He was a visiting researcher at the University of California Berkeley (2006-2010). Rustam is the co-author of Security in Central Asia: A Methodological Framework for Analysis (Military Security Sector) (2006).

Irina Chernykh holds a PhD in Political Science and a PhD in International Relations History and Theory. She is currently working as project manager of the Rosa Luxemburg Stiftung in Central Asia and as a part-time professor at the Kazakh-Germany University (Almaty, Kazakhstan). She was Chief Research Fellow at the Kazakhstan Institute for Strategic Studies under the President of the Republic of Kazakhstan (2011-2020), Head of the Applied Analysis Department at the Institute of Political Solutions (2009-2010), and Head of the Area Studies Department at the al-Farabi Kazakh National University (2007-2009).

Frank Evers is a researcher at the Institute for Peace Research and Security Policy at the University of Hamburg (IFSH) and Deputy Head of the Institute's Centre for OSCE Research (CORE), responsible for OSCE-related projects. He worked as an adviser at the OSCE Office in Yerevan and as Deputy Head of the OSCE Mission to Ukraine in Simferopol (Crimea). He was one of the initiators of the Yerevan Aarhus Centre and a leading contributor to designing and establishing the OSCE Academy in Bishkek, the Diplomatic School of Armenia, the OSCE Network of Think Tanks and Academic Institutions, and special training courses for incoming OSCE Chairs. His interests range from OSCE conflict management to transnational security issues, focusing regionally on the East Slavic countries, the South Caucasus, and Central Asia.

Daniel S. Hamilton is the Austrian Marshall Plan Foundation Distinguished Fellow and Director of the Global Europe Program at the Woodrow Wilson International Center for Scholars. He is a faculty member at Johns Hopkins University's School of Advanced International Studies, where he directs the School's postdoctoral program on The United States, Europe, and World Order. He served as Deputy Assistant Secretary of State for European Affairs, with direct responsibility for US policy towards the OSCE and transatlantic security issues. Recent publications include Uncommon Cause: The Future of the OSCE and Europe Whole and Free: Vision and Reality. 
Argyro Kartsonaki holds a $\mathrm{PhD}$ in International Relations from the University of Birmingham. She has expertise in secession and war-to-peace transitions after civil wars. Her research focuses on the prevention of civil war recurrence and has received funding from the United States Institute of Peace and the Social and Economic Research Council. Recent single and co-authored publications include PAIC: a New Dataset on Political Agreements for the Termination of Intra-State Conflicts 19892016; Playing with Fire: an Assessment of the EU's Approach of Constructive Ambiguity on Kosovo's Blended Conflict; and The False Hope of Remedial Secession: Theory, Law and Reality. She is the author of the book Breaking Away: Kosovo's Unilateral Secession.

Ana Krstinovska is the founder and president of ESTIMA, a North Macedonia-based think tank, and a member of the Permanent Council for foreign policy of North Macedonia. Previously, she worked as a foreign policy advisor, State Secretary for European Affairs in the North Macedonian government, and the first secretary of North Macedonia's Mission to the EU in Brussels. She is a $\mathrm{PhD}$ candidate in International Relations at St Cyril and Methodius University in North Macedonia and holds an MA in EU studies from the College of Europe in Bruges, Belgium. Her research interests cover the Western Balkans, the EU, and China, focusing particularly on governance and foreign policy.

Eukasz Kulesa is Deputy Head of Research at the Polish Institute of International Affairs (PISM). From 2019 to 2021, he participated in the OSCE-focused Cooperative Security Initiative. He worked as Research Director at the European Leadership Network (2014-2019). From 2010 to 2012 he was Deputy Director of the Strategic Analyses Department at the Polish National Security Bureau. His publications include Reinventing Nuclear Nonproliferation and Disarmament as Cooperative Endeavors (CFR, 2021); Dilemmas of Arms Control: Meeting the Interests of NATO's North-Eastern Flank (ICDS, 2020); Towards a More Stable NATO-Russia Relationship (ELN, 2019); and The Future of Conventional Arms Control in Europe (Survival, 2018).

Barbara Kunz holds a PhD from Stockholm University. She has been a researcher at IFSH since 2019, where she primarily works on European security and defence affairs. Prior to joining IFSH, she worked at the Institut français des relations internationales, the Genshagen Foundation, the Bertelsmann Stiftung, and the Centre for Baltic and East European Studies. Barbara Kunz studied political science and international relations at the Institut d'études politiques (Sciences Po) in Paris. During her doctoral studies, she was a visiting fellow at the Center for Transatlantic Relations (SAIS/Johns Hopkins University) in Washington, DC.

Lars-Erik Lundin holds a PhD in Political Science/International Relations. He is a former Swedish diplomat (1976-1996) whose focus is security policy, including in the CSCE/OSCE (1984-86 and 1990-1996). Lundin served in the European Commission (1996-2009) and as EU Ambassador to the OSCE (2009-2011). He is a distinguished Associate Fellow at SIPRI and an elected member of the Swedish Royal Academy 
of War Sciences. He conducted an official inquiry in Sweden into the Treaty on the Prohibition of Nuclear Weapons in 2019. Lundin is the author of a Handbook on EU and Security (2015) and co-author of books on the southern dimension of European security (2020) and Swedish security policy (forthcoming).

Giray Sadik is the founder and director of the European Studies Research Center at the Ankara Yildirim Beyazit University, Turkey, where he is Professor and Chair in the Department of International Relations, Faculty of Political Science. He was an Eisenhower Fellow at the NATO Defense College in Rome and a Swedish Institute Postdoctoral Fellow at Malmö University, Sweden. He received his PhD in Political Science from the University of Georgia, USA, specializing in International Relations and Comparative Politics. His recent research is mainly on European security and foreign policies, focusing on Euro-Atlantic strategies on countering terrorism and hybrid threats.

Andrei Zagorski is Head of Disarmament and Conflict Resolution Studies at the Primakov National Research Institute of World Economy and International Relations (IMEMO) of the Russian Academy of Sciences. He is also Professor of International Relations at the Moscow State Institute of International Relations. He is a member of the Russian International Affairs Council, the trilateral Deep Cuts Commission, and the Steering Committee of the OSCE Network of Think Tanks and Academic Institutions. Previously, he served as Vice Rector of MGIMO; Senior Vice President of the EastWest Institute (Prague); Faculty Member of the Geneva Centre for Security Policy; and Deputy Director of the Institute for Applied International Research, Moscow. 
